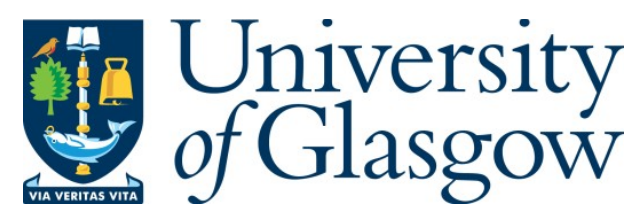

Dineva, D., Breitsohl, J., Garrod, B. and Megicks, P. (2020) Consumer responses to conflict-management strategies on non-profit social media fan pages. Journal of Interactive Marketing, 52, pp. 118-136.

(doi: 10.1016/j.intmar.2020.05.002)

This is the Author Accepted Manuscript.

There may be differences between this version and the published version. You are advised to consult the publisher's version if you wish to cite from it.

$\underline{\text { https://eprints.gla.ac.uk/222309/ }}$

Deposited on: 18 August 2020

Enlighten - Research publications by members of the University of Glasgow http://eprints.gla.ac.uk 


\section{Journal of Interactive Marketing \\ Consumer Responses to Conflict-management Strategies on Non-profit Social Media Fan Pages \\ --Manuscript Draft--}

\begin{tabular}{|l|l|}
\hline Manuscript Number: & INTMAR-D-19-00060R2 \\
\hline Article Type: & Full Length Article \\
\hline Keywords: & $\begin{array}{l}\text { conflict management; customer misbehavior; uncivil consumer-to-consumer } \\
\text { communication; social media fan pages; non-profit organizations; self and others } \\
\text { benefits }\end{array}$ \\
\hline Corresponding Author: & $\begin{array}{l}\text { Denitsa Dineva } \\
\text { Cardiff University } \\
\text { Cardiff, UNITED KINGDOM }\end{array}$ \\
\hline First Author: & Denitsa Dineva \\
\hline Order of Authors: & Denitsa Dineva \\
\hline & Jan Breitsohl \\
\hline Brian Garrod \\
\hline Response to Reviewers: & Philip Megicks \\
\hline We have included a set of revision notes in a separate Word document, as requested \\
\hline
\end{tabular}




\section{Short title:}

Managing Consumer Conflicts Online

\section{Full title:}

Consumer Responses to Conflict-management Strategies on Non-profit Social Media Fan Pages

This research did not receive any specific grant from funding agencies in the public, commercial, or not-for-profit sectors.

Declarations of interest: none 


\section{Authors' details:}

Corresponding author: Dr. Denitsa Dineva

Affiliation: Cardiff Business School, Cardiff University, UK

Postal address: Aberconway Building, Colum Road, Cathays, Cardiff, CF10 3EU

Phone: +44 (0)29 20876407

Email: DinevaD@cardiff.ac.uk

Biographical note: Denitsa Dineva is an Assistant Professor (Lecturer) in Marketing and Strategy at Cardiff Business School, Cardiff University (UK). Her research interests include conflict management, aggressive consumer-to-consumer communication, online communities and digital marketing in for-profit and non-profit contexts.

Second co-author: Dr. Jan Breitsohl

Affiliation: Adam Smith Business School, University of Glasgow, UK

Postal address: University Ave, Glasgow, G12 8QQ

Phone: +44 (0)141 3303993

Email: Jan.Breitsohl@glasgow.ac.uk

Biographical note: Jan Breitsohl is an Associate Professor (Senior Lecturer) in Digital Marketing at Adam Smith Business School, University of Glasgow (UK). His academic interests focus on the dark side of digital marketing, in particular, consumer aggression, social media scandals and corporate response strategies.

Third co-author: Professor Brian Garrod

Affiliation: School of Management, Swansea University, UK

Postal address: Bay Campus, Fabian Way, Swansea, SA1 8EN 
Email: brian.garrod@swansea.ac.uk

Phone: +44 (0)1792604211

Biographical note: Brian Garrod is a Professor in Marketing at Swansea University School of Management, Swansea University (UK). His research interests lie in the marketing and management of tourism, focusing particularly on sustainable tourism destinations.

Fourth co-author: Dr. Philip Megicks

Affiliation: Southampton Business School, University of Southampton, UK

Postal address: 2/6033 Southampton Business School, University of Southampton,

Highfield, Southampton SO17 1BJ, UK

Email: P.R.Megicks@soton.ac.uk

Phone: + $44(0) 2380596716$

Bibliographical note: Phil Megicks is an Associate Professor in Marketing Southampton Business School, University of Southampton (UK). His research interests lie in the fields of marketing strategy and consumer behavior in small service sector organizations, particularly retailing. He has also developed strands of research in ethical marketing and consumer's ethical decision making. His research has been published in a range of internationally recognized marketing, retailing, tourism, and production management journals. 


\section{Highlights}

- Offers managers first insights into a selection of strategies for specific contexts

- Five strategies are recorded: non-engaging, censoring, educating, bolstering, mobilizing

- A hitherto uncovered conflict management strategy termed 'mobilizing' is identified

- Imposing civility as a condition to participation is perceived most favorably

- Self-benefit and other-benefit conflicts require different management strategies 


\title{
Consumer Responses to Conflict-management Strategies on Non-profit Social Media Fan Pages
}

\begin{abstract}
Past research has demonstrated that consumer-to-consumer (C2C) conflicts, here defined as uncivil social interactions between consumers, can have a negative impact on consumers' engagement in social media fan pages (SMFPs). Little is known, however, about how best to manage such conflicts, and this is particularly true in the non-profit context. This paper follows a mixed-method approach in order to address this research gap. Study 1 uses a netnography of a non-profit organization (NPO) to examine how it manages $\mathrm{C} 2 \mathrm{C}$ conflicts on its SMFP. Five different conflict-management strategies are identified: non-engaging, censoring, bolstering, educating, and mobilizing. These findings inform Study 2, an online experiment to test how different strategies affect consumers' attitudes towards the conflictmanagement approach itself and towards the NPO's social responsibility. Study 2 also accounts for the moderating effect of the conflict content, differentiating between whether a conflict relates to a consumer's self-benefit or the benefit to others. Our results offer insights for practitioners into preferable content management strategies when consumers engage in different types of conflict on social media platforms.
\end{abstract}

Keywords: conflict management; customer misbehavior; uncivil consumer-to-consumer communication; social media fan pages; non-profit organizations; self and others benefits; 


\section{Introduction}

Non-profit organizations (NPOs) have fan pages on social media sites such as Facebook to facilitate consumer-to-consumer $(\mathrm{C} 2 \mathrm{C})$ interactions and encourage social action (Saxton \& Waters, 2014). These permit NPOs to promote an ethical cause to a global audience in an interactive way (Waters, Burnett, Lamm \& Lucas, 2009). Recent studies have shown that nonprofit social media fan pages (SMFPs) successfully attract and engage individuals who wish to contribute to the welfare of society by engaging in behaviors that support the NPO's cause (Guo \& Saxton, 2014; Saxton \& Wang, 2014). Such behaviors include giving (i.e. donations and volunteering) (Liu \& Aaker, 2008); activism (i.e. signing petitions, lobbying and spreading word-of-mouth) (Lee, Kim, Kim \& Choi 2014); and ethical purchase behaviors (i.e. buying ethical products or refraining from buying unethical ones) (Sudbury-Riley \& Kohlbacher, 2016).

While non-profit fan pages attract participants who appear to support the same cause, disagreements frequently occur due to the global reach of SMFPs. Previous research has suggested that these may be a result of SMFP users' dissimilar backgrounds and personal values (de Almeida, Dholakia, Hernandez \& Mazzon, 2014; Ewing, Wagstaff \& Powell, 2013), or because they have different opinions about what the NPO's mission involves or how it should be pursued (Carrington, Neville \& Whitwell, 2014; Freestone \& McGoldrick, 2008). Such disagreements can take the form of one consumer verbally attacking another consumer, who then reciprocates in kind (Chan \& Li, 2010; Ilhan, Kübler \& Pauwels, 2018). We term this phenomenon ' $\mathrm{C} 2 \mathrm{C}$ conflict'. As noted by others, $\mathrm{C} 2 \mathrm{C}$ conflicts can range from being mild in tone, e.g. name-calling, teasing and provocation, to being very strong, e.g. harassment and threats (Breitsohl, Roschk \& Feyertag, 2018; Ewing et al., 2013). To illustrate this, the excerpt shown in Figure 1 demonstrates a typical $\mathrm{C} 2 \mathrm{C}$ conflict resulting from one consumer questioning the validity of another consumer's beliefs regarding veganism. The excerpt also 
illustrates how an NPO may choose to intervene in the conflict by affirming a supporter's comment.

\section{Insert Figure 1 here}

Previous research suggests that similar conflicts can have a negative impact on both consumers (Gebauer, Füller \& Pezzei, 2013; Thomas, Price \& Schau, 2013) and organizations (Fisk et al., 2010). C2C conflicts can cause consumers psychological and emotional distress (Pew, 2017), making them less likely to continue to interact on the SMFP and obtain functional benefits (e.g. cause-related information) from it (Gebauer et al., 2013). The NPOs concerned could, meanwhile, experience a loss of credibility, especially if they are deemed to have failed to manage the C2C conflict effectively (Pfeffer, Zorbach \& Carley, 2014).

Despite these negative outcomes for both consumers and organizations, the marketing literature presently lacks research on how NPOs should manage C2C conflicts when they arise, as evidenced by calls of de Valck (2007) and Husemann, Ladstaetter and Luedicke (2015). To date, only a few studies have examined what strategies organizations use to address $\mathrm{C} 2 \mathrm{C}$ conflicts (Bacile, Wolter, Allen \& Xu, 2018; Dineva, Breitsohl \& Garrod, 2017; Hauser, Hautz, Hutter \& Fuller, 2015). It is noteworthy that these studies focus exclusively on the for-profit context. We argue here that the non-profit context is different and deserves specific attention. Compared with for-profit, commercially oriented SMFPs, NPOs pursue value-laden causes that are largely dependent on engaged consumer interactions in order to encourage action towards a social/ethical cause (Lovejoy \& Saxton, 2012; Waters et al., 2009). Moreover, in comparison with for-profit SMFPs, which are characterized by weaker member commitment, members of non-profit SMFPs frequently display extreme commitment in the form of brand/cause defense and a deeper level of participation in the community (de la Peña, Amezcua \& Sepúlveda, 2018). Such extreme commitment can, in turn, amplify the frequency and severity of conflicts when 
they occur, which necessitates a better understanding of the specific conflict-management practices adopted in these non-profit fan pages.

The first contribution of the present study is therefore to investigate the kind of conflictmanagement strategies an NPO uses on social media. To this end, the purpose of Study 1 is to uncover strategies used by PETA ('People for the Ethical Treatment of Animals') on their Facebook fan page to manage $\mathrm{C} 2 \mathrm{C}$ conflict, following a three-month netnography of the fan page. To gain a more complete understanding of the context in which conflict management takes place, our analysis further distinguishes between two main types of conflict content: selforiented, which refers to conflict content revolving around issues related to the self, and otheroriented, which refers to conflict content revolving around issues related to others.

The extant knowledge on social media conflict-management strategies is further limited to observational studies, with a need for more quantitative research. In particular, authors have called for experimental studies that are able to measure how such strategies are perceived by consumers (Gensler, Völckner, Liu-Thompkins \& Wiertz, 2013; Ilhan et al., 2018; Johnson \& Lowe, 2015). Consequently, our second contribution relates to the investigation of which strategy leads to the most favorable consumer attitudes. Study 2 thus employs our observations from Study 1 in an experimental design that compares how different conflict-management strategies, taking into account the types of conflict, affect consumers' attitudes towards the NPO and its organizational social responsibility. We chose these two outcome variables since previous research suggests, but has not yet verified, that consumers regard the governance of interactions in SMFPs, and particularly those that are hostile in nature (Illia et al., 2017; Pew, 2017), to be the responsibility of organizations (Felix, Rauschnabel \& Hinsch, 2017). Therefore, we aim to establish how an organization's perceived social responsibility is affected by different management strategies, as well as consumers' attitudes towards the management 
of conflicts itself. Taken together, the two studies aim to provide new insights into conflictmanagement practices adopted in an online non-profit context.

\section{Literature Review}

\subsection{C2C Conflicts in a Non-profit Context}

Previous research has found $\mathrm{C} 2 \mathrm{C}$ conflicts in a non-profit context to occur between supporters of the cause the NPO is promoting (Schröder \& McEachern, 2004). Pro-social consumers consider a range of ethical issues when making consumption-related decisions (Shaw \& Newholm, 2002). Hence, opinions about these ethical issues, what the cause constitutes and how it should be pursued often differ, causing $\mathrm{C} 2 \mathrm{C}$ conflict to occur. In contrast, due to the global reach of fan pages in the social media, $\mathrm{C} 2 \mathrm{C}$ conflict can also take place between supporters and non-supporters of the NPO's stated cause (Zane, Irwin \& Reczek, 2015). Reasons for such conflicts may stem from differences in personal values, a lack of information, skepticism or cynicism towards ethical behavior (Bray, Johns \& Kilburn, 2011; Burke, Eckert \& Davis, 2014), or simply from the joy of provoking others (i.e. 'trolling') (Buckels, Trapnell \& Paulhu, 2014). Bray et al.'s (2011) study, for example, suggests that some consumers dismiss the positive impact of ethical consumption on humans, animals and the environment on the grounds of it essentially being little more than a marketing strategy, designed to enable companies to charge premium prices for ordinary products. In addition, Zane et al. (2015) confirm that less-ethical consumers sometimes denigrate supporters of ethical consumption. Such denigration, which can take the form of online $\mathrm{C} 2 \mathrm{C}$ conflict, is said to arise from the selfthreat inherent to making social comparisons when encountering opinions and values different from one's own.

More recently, research has started to focus on the negative outcomes of $\mathrm{C} 2 \mathrm{C}$ conflicts. Studies suggest that $\mathrm{C} 2 \mathrm{C}$ conflicts can deter individuals from engaging in constructive 
discussions with other like-minded users and the company host (Anderson et al., 2014; Seraj, 2012). Decreased levels of involvement in the fan page can in turn make it more difficult for NPOs to encourage people to commit to actions concerning the causes they are promoting (Lovejoy \& Saxton, 2012). Such activism could be private, for example making ethical consumption choices or donating money, or social, for example protesting, lobbying or spreading word-of-mouth about the cause.

\subsection{Extant Knowledge on Conflict Management}

Ensari, Camden-Anders and Schlaerth (2015) define conflict management as a collection of practices used by organizations to intervene in disputes. Few studies have empirically examined conflict management in online settings; fewer still have focused on NPOs, as

demonstrated in Figure 2. The extant literature on the management of (uncivil) social interactions in online environments focuses on providing conceptual recommendations, examines for-profit or small-scale, consumer-hosted communities, and offers preliminary findings based on conflict-management theories and typologies designed for offline (organizational) conflict management. Table 1 synthesizes notable studies that fall into this domain.

\section{Insert Figure 2 here}

Some early conceptual insights into the roles that companies choose to adopt when managing social interactions between consumers in online settings are offered by Godes et al. (2005). The authors distinguish between four roles that a company may adopt: observer, mediator, moderator and participant. These are not considered to be mutually exclusive and which particular option or combination of options is chosen will depend on the type of $\mathrm{C} 2 \mathrm{C}$ interaction (positive versus negative) as well as the context. Likewise, more recently, Homburg, Ehm and Artz (2015) identified two generic company roles in managing C2C 
discussions in an online community setting: passive and active. In choosing passive engagement, the company offers users a platform with which they can interact and does not engage in conversations among them. Active participation, in contrast, involves direct interactions to stimulate user-generated content (Gensler et al., 2013).

Specifically in the context of for-profit SMFPs, Dineva et al. (2017) demonstrated that across six product and service categories, most firms adopted a passive role during $\mathrm{C} 2 \mathrm{C}$ conflicts. The remainder of the strategies proposed by Dineva et al. (2017) comprised providing corporate or product information to rectify what are perceived to be incorrect consumer comments, affirming consumers who defend the brand, pacifying conflict by asking one or more consumers to adjust their communication style and censoring consumer comments. These findings were supported by a study examining consumer incivility, which demonstrated that in 11 SMFPs companies generally did not intervene in uncivil $\mathrm{C} 2 \mathrm{C}$ communication (Bacile et al., 2018).

Others have put forward the concept of community-governing mechanisms (Mathwick, Wiertz \& De Ruyter, 2008; Schau, Muñiz \& Arnould, 2009). These mechanisms involve articulating expectations of acceptable behavior, comprised of, for instance, keeping criticism constructive, challenging negative comments, and realigning interactions to maintain a positive community environment. Similarly, based on an in-depth review of the literature, Sibai, de Valck, Farrell and Rudd (2015) differentiate between two C2C conflict-moderation roles that take place in online communities: interaction maintenance and interaction termination. Interaction maintenance is intended to ensure that $\mathrm{C} 2 \mathrm{C}$ interactions remain functional and involves monitoring and pacifying interactions through rewarding positive behaviors and sanctioning negative behaviors. Interaction termination occurs when $\mathrm{C} 2 \mathrm{C}$ interactions become dysfunctional and entails ignoring members or excluding them from the online community. 
In line with maintaining or terminating hostile interactions, an observational study outlined the behavioral strategies used in a feminist online forum to deal with flaming (i.e. hostile expression of strong emotions) among its members (Lee, 2005). The proposed strategies can be categorized into three groups: competitive-dominating, cooperative-integrating and avoiding. The competitive-dominating strategy involves threats, persuasion and realignment through requesting compliance. Cooperative-integrating strategies suggest an overall consideration of others, including compromising, offering concessions, apologizing and showing solidarity. Avoiding strategies, in contrast, comprise of activities that aim to ignore the conflict, including making jokes, being silent and withdrawal.

Matzat and Rooks (2014) drew a contrast between positive (reward) and negative (punishment) conflict-management strategies. According to the authors, positive conflict management involves rewarding desirable behaviors (e.g. public appreciation for appropriate community engagement), while negative conflict management describes punishing undesirable behavior (e.g. public disapproval of unwanted community engagement behaviors). In a study on addressing public scandals in online settings, Hauser et al. (2017) continued this debate by comparing the effects of assertive versus cooperative strategies. Assertive conflict management is represented by competing, obliging, and avoiding, while cooperative conflict management involves accommodating, yielding and integrating strategies.

Lastly, a netnographic study on different types of consumer conflicts in a user-hosted online community offers findings into conflict-management practices as a sub-theme (Husemann et al., 2015). The authors divide C2C conflicts into routinized (i.e. positive for the community) and transgressive (i.e. negative for the community) and recommend different practices depending on the type of conflict. The authors argue that routinized conflicts warrant nurturing because they are seen as beneficial for the community, while transgressive conflicts 
should be dealt with by excluding members from the online community due to their negative impact on the welfare of its members.

\section{Insert Table 1 here}

\subsection{The For-profit versus Not-for-profit Context}

While some of these strategies may also apply in non-profit fan pages, the different characteristics of non-profit and for-profit fan pages suggest that the nature of conflict - and hence what needs to be done, if anything, to manage it - is likely to differ (Aaker, Vohs \& Mogilner, 2010; Bernitter, Verlegh \& Smit 2016; Thach \& Thompson, 2007). Hosts of forprofit SMFPs pursue monetary goals and the main objective is to stimulate interactions between users, and ultimately increase their consumption expenditure (Habibi, Laroche \& Richard, 2014; Naylor, Lamberton \& West, 2012). When such interactions turn hostile, hosts of forprofit fan pages have a responsibility to pacify these in order to maintain constructive discussions and continued consumer engagement and participation in the fan page (Van Noort \& Willemsen, 2012). Past studies have shown that such management will include requesting consumers to adjust their communication behavior (Dineva et al., 2017), correcting/disagreeing with consumers (Habel, Alavi \& Pick, 2017) or using more authoritative styles (e.g. sanctioning undesirable behaviors) to resolve the conflict (Matzat \& Rooks, 2014; Sibai et al., 2015).

In contrast, non-profit SMFPs measure their success by how far their efforts contribute to improving the welfare of their target group (Hassay \& Peloza, 2009). Thus, the host of a nonprofit SMFP has ideological motives to increase interactions on the fan page, which can create further discussions around the ethical issue that is being promoted (Waters \& Jamal, 2011). Consequently, NPOs are likely to use more inspirational, value-laden conflict-management strategies (Chen, Lune \& Queen, 2013; Thach \& Thompson, 2007). Indeed, some NPOs aim to generate public controversy around their promoted cause in order to encourage activism 
(Botner, Mishra \& Mishra, 2015; Kronrod, Grinstein \& Wathieu, 2012). Thus, strategies that suppress the creation of controversy around the ethical issues that are promoted may be seen as counterproductive and are, therefore, unlikely to take place. These contentions have, however, not been thoroughly tested.

\section{Study 1}

\subsection{Method}

Study 1 aimed to address the following research question:

What strategies are used by NPOs to manage C2C conflict on their SMFPs?

Following Ertimur and Gilly (2012), we conducted a non-participatory netnographic study of a Facebook fan page hosted by PETA: an American NPO with over 5.5 million fan page members (https://www.facebook.com/official.peta). Topics discussed in the community revolve around animal rights, including vegan lifestyles, animal testing and the use of animals for the purpose of entertainment. We chose a non-participatory approach to studying the online environment, because it allowed for more naturalistic and unobtrusive research (Wu \& Pearce, 2013). Moreover, community members tend to alter socially undesirable behavior if they know they are being observed (Jerolmack \& Khan, 2014). Since hostile C2C interactions are often deemed to be socially undesirable, we considered it essential not to participate in any of the discussions, but merely to monitor them. Figure 3 illustrates the research procedure undertaken in Study 1.

\section{Insert Figure 3 here}

Prior to the data collection, the lead researcher spent a month observing the page as part of the entrée stage (Kozinets, 2002, 2015). This was done to ensure that: (1) there is familiarity with the organization and its context, (2) there is presence of between-member interactions of the type required for the present study (i.e. C2C conflicts), and (3) there is evidence of content 
moderation by the organization. Furthermore, as part of the entrée stage, the lead researcher was able to develop a set of semantics related to the examined online environment and context, as demonstrated in Table 2. These allowed the researcher to differentiate between negative (hostile/counterproductive) and positive (constructive) $\mathrm{C} 2 \mathrm{C}$ conflicts, as well as to distinguish these from other types of interactions, with the former (i.e. negative $\mathrm{C} 2 \mathrm{C}$ conflict) being of interest in this study. It was further confirmed that the majority of the $\mathrm{C} 2 \mathrm{C}$ conflict that occurred on the fan page was between groups of supporters and non-supporters of the organization (as opposed to in-group conflict), suggesting that such conflict was the result mainly of the different values and belief systems held by the members of the two groups.

\section{Insert Table 2 here}

During three months of observing a total of 194 organizational posts and 165,275 individual comments, the researchers agreed that no new insights were emerging from the data; a case of theoretical saturation (Strauss \& Corbin, 1998; Fusch \& Ness, 2015). A total of 343 conflict episodes (3,468 individual comments) and 78 organizational interventions had been recorded by this time.

\subsection{Data Analysis}

To analyze the data, we followed a six-stage thematic analysis approach, as recommended by Braun and Clarke $(2006,2014)$. The first phase involved familiarization with the dataset for the purpose of identifying relevant data. Next, the data were analyzed in order to generate initial data-driven codes. The codes were then subsumed based on their unifying features, which generated our themes, i.e. conflict-management strategies. The themes were reviewed in relation to the coded data and the entire data set, while labels were assigned, and definitions developed to describe the underpinning meaning of each theme. Given that previous studies have identified a tendency for organizations to adjust their communication strategies in 
accordance with particular characteristics of a C2C conflict (e.g. (Barcelos, Dantas \& Sénécal, 2018; Husemann et al., 2015; Schröder \& McEachern, 2004), we further analyzed whether these conflict-management strategies would vary in relation to the content of the content. This led to the development of an additional theme (i.e. conflict content orientation).

Investigator triangulation was employed to enhance the study's validity (Reeves, Kuper \& Hodges, 2008). This process involved researchers comparing and discussing their codes and interpretations of the data over several rounds of analysis. More specifically, three researchers independently coded 86 conflict scenarios from the total dataset and upon completion of the triangulation excluded 11 conflict scenarios. This resulted in an acceptable inter-rater reliability index of .87 , calculated using proportional agreement (i.e. the proportion of total pairwise agreements between coders) (Rust \& Cooil, 1994). The names in the examples provided here were all changed to ensure anonymity.

\subsection{Results}

Our analysis yielded five conflict-management strategies, as illustrated in Table 3. Nonengaging is a conflict-management strategy wherein the organization does not intervene in a conflict. This was the most commonly used strategy, irrespective of the intensity and length of the $\mathrm{C} 2 \mathrm{C}$ conflict. In contrast, a more active and authoritative strategy is censoring, which involves the organization removing certain comments. Censoring was observed in two $\mathrm{C} 2 \mathrm{C}$ conflicts, both of which involved the users specifically requesting for the content to be removed. Unlike censoring, bolstering involves the organization actively posting comments to affirm views expressed by like-minded users. This strategy broadly involves the organization thanking supporters of the organization's cause (e.g. users who follow a vegan lifestyle) or agreeing with their comments in support of issues relating to the cause the organization is promoting. Educating, in comparison, refers to providing consumers with additional 
information about an ethical issue. During our observations, the organization used educating in $\mathrm{C} 2 \mathrm{C}$ conflicts where one or more users partly or wholly disagreed with the organization's views on a given ethical issue. Lastly, mobilizing involves the organization encouraging users to take action with regard to the ethical issue that caused the $\mathrm{C} 2 \mathrm{C}$ conflict to happen. This strategy enables the organization to further promote its views on certain ethical issues and thus, arguably, to promote the organization's objectives. In our observations, mobilizing was frequently complemented by the provision of additional information (e.g. an external link), possibly to strengthen the impact of the message.

\section{Insert Table 3 here}

Our analysis of the conflict content also identified two main orientations: conflict content revolving around the self (e.g. a vegan lifestyle as a personal choice, the implications of a vegan diet on personal health) and conflict content revolving around others (i.e. the implications of personal or collective consumption choices for animal welfare and animal rights). The latter accounted for the majority of conflicts, as shown in Table 3. However, we did not uncover any patterns in the data to support that PETA differentiated between these different orientations and adjusted their conflict-management strategies accordingly.

\subsection{Discussion}

The findings of Study 1 provide insight into our research question by identifying strategies that an NPO employs to manage $\mathrm{C} 2 \mathrm{C}$ conflicts on their SMFP and thus contribute to the interactive marketing literature. First, we identify mobilizing: a strategy that has not previously been discussed in studies on consumer-conflict management. Mobilizing represents one of the key functions of NPOs that utilize online communities in the social media: requesting individuals to take action (Guo \& Saxton, 2014; Lovejoy \& Saxton, 2012). In our observations, mobilizing is often used in combination with an informative statement, arguably to align the organization's 
mission and objectives to the requested action (Vázquez, Álvarez \& Santos, 2002). In line with previous studies (Lovejoy \& Saxton, 2012; Saxton \& Wang, 2014), we propose that such an approach is meant to empower consumers to be more self-directed in their decisions regarding ethical consumption and participation in advocacy programs.

An additional insight is that the remaining conflict-management strategies (i.e. nonengaging, censoring, educating and bolstering) were similar to the ones uncovered by others in a for-profit context (Dineva et al., 2017; Sibai e al., 2015). Thus, these strategies complement the scarce findings of the extant literature. Non-engaging is the most passive and frequently used of all strategies observed. The strategy is similar to what Godes et al. (2005) call taking the 'observer' role, whereby the organization simply observes interactions and collects information about fan page users (see also Homburg et al., 2015). While other studies have confirmed the regular use of non-engaging in for-profit settings (e.g. Bacile et al., 2018), the absence of moderation in a non-profit context does appear to be contradictory as NPOs typically endorse communal interactions (Hassay \& Peloza, 2009). NPO community moderators are thus expected to take action with respect to uncivil $\mathrm{C} 2 \mathrm{C}$ communication, rather than to ignore it.

Censoring, in contrast, is an active and authoritative strategy. As noted in studies on both non-profit (Husemann et al., 2015) and for-profit contexts (Sibai et al., 2015), censoring is a means of sanctioning undesirable user behavior. It is not surprising that this strategy was used infrequently and exclusively in situations where users demand it. Past research has demonstrated that NPOs actively promote their commitment to the diversity of opinions (Guo \& Saxton, 2014; Van Noort \& Willemsen, 2012), and thus censoring may appear controversial in this context. 
Educating is a less-intrusive strategy in this regard because it involves the company providing educational information about an ethical issue. Similar to Dineva et al.'s (2017) findings with respect to for-profit brand fan pages, the organization uses educating to address those users who possess incomplete information on the organization or issues of animal rights or only partly agree with the organization's opinion about an ethical issue. This strategy can be further related to Lovejoy and Saxton's findings (2012), who demonstrate that informationsharing is a key function of non-profits' communication on Twitter, covering information about the organization's activities and news with the purpose to educate consumers on ethical issues. The final strategy, bolstering, represents a more relationship-oriented strategy. Our findings demonstrate that bolstering is often used as a strategy to invoke positive feelings among users and encourage them to continue doing what they are being praised for (de Hooge, Verlegh \& Tzioti, 2014; Schamari \& Schaefers, 2015). This is crucial in the present context because continued support through taking action, donations and word-of-mouth is considered to be key to enhancing animal welfare (Lovejoy \& Saxton, 2012).

Our findings further show that the majority of $\mathrm{C} 2 \mathrm{C}$ conflicts revolve around content that discusses collective action and benefits (i.e. other-oriented) as opposed to personal benefits (i.e. self-oriented). Past studies provide support for these orientations in a non-profit context and show that while one highlights that a certain ethical action is performed to benefit the self solely, the other posits that the same action is invariably socially-oriented (Fisher, Vandenbosch \& Antia, 2008; Green \& Peloza, 2014). Scholars have further demonstrated that consumers' attitudes are more strongly influenced when organizational communications emphasize the benefit to the self (as opposed to the benefit to others) (Ye, Teng, Yu \& Wang 2015). It is thus a somewhat surprising finding that other-oriented content dominates the fan page, given that the goal of the NPO is to change or reinforce certain individual behaviors. Since research has demonstrated that the two orientations have a potentially differential impact 
on consumers' attitudes towards organizational communication (management) (Green \& Peloza, 2014; Yang, Lu, Zhu \& Su, 2015; Ye et al., 2015), we included these in Study 2 in order to test whether this is relevant in a conflict-management context, and whether it may be useful for NPOs such as PETA.

\section{Study 2}

Study 2 is guided by the following research question:

Which conflict-management strategy is the most effective?

We explored effectiveness through two consumer outcomes (i.e. dependent variables), namely consumers' attitudes towards the conflict management (ATCM) itself and attitudes towards the organization's social responsibility (ATOSR). These were deemed important, since previous research suggests that consumers distinguish between different styles of organizational communication on social media (Amatulli et al., 2017; Gretry, Horváth, Belei \& van Riel, 2017), and that such communication, whether perceived appropriate or not by consumers, directly influences an organization's reputation (Wang, Yu \& Wei, 2012). Thus, assessing attitudes towards the conflict-management approach itself, as well as towards the organization's social responsibility, provides an understanding of the level of appropriateness of different strategies used by an NPO to address C2C conflict. Given the lack of quantitative findings on the effect of the strategies under investigation, and the explorative nature of this study, a research question was favored over providing specific hypotheses, following others (e.g. Roschk \& Kaiser, 2013; Waters, 2007).

\subsection{Research Design and Sample}

Based within an online survey, we conducted a randomized 2 (content orientation) x 6 (management strategies) between-subjects scenario experiment. Subjects were recruited through a Qualtrics online panel and consisted of 512 US individuals (68\% female, $M_{\text {Age }}=44$ 
years) with an average income of over $\$ 2,000$ per month, and aged 18 to 65 . All subjects visited SMFPs at least once a week and, on average, posted comments two or three times per month.

\subsection{Scenario Development}

The 12 experimental scenarios were developed in close relation to our observations in Study 1 . In the beginning, participants were asked to read a Facebook post by a fictitious NPO called the World Society for Ethical Food Consumption (WSEFC) about the implications of consuming dairy products. In the comments section below the organization's post, respondents were shown a $\mathrm{C} 2 \mathrm{C}$ conflict which consisted of two conditions related to the content of the conflict (Manipulation 1 - Conflict content orientation: Self vs Others) (Appendix A). The first condition showed a conflict about personal health and was meant to activate respondents' selffocus, i.e. considering the implications of an issue directly related to their own health. The second condition showed a conflict about animal welfare and intended to activate respondents' focus on others, i.e. considering the implications of a consumption issue related to the welfare of animals.

Subsequently, each subject was randomly allocated to one of six conditions, each portraying a different management strategy in response to the $\mathrm{C} 2 \mathrm{C}$ conflict (Manipulation 2 Conflict-management strategy) (see Appendix B). The six conditions included the five strategies identified in Study 1, and one additional strategy, 'realignment'. We added a realignment strategy for two reasons. First, studies in the for-profit literature suggest that realignment in the form of enforcing the company rules leads to favorable customer attitudes and perceptions (Habel et al., 2017; Skålén, Pace \& Cova, 2015). Second, there is evidence from past research that realignment is frequently employed as a strategy to manage online environments (Hauser et al., 2017; Matzat \& Rooks, 2014). Based on our observations of PETA's approach to conflict management, we suggest that realignment may represent an 
additional, beneficial strategic option that is worth exploring. Moreover, including realignment allowed us to compare our results to findings from research on for-profit communities. We therefore included realignment based on its potential to positively affect consumers' attitudes in the present context. We define realignment as 'asking one or more users in a SMFP to adjust their communication style or behavior' (Skålén et al., 2015).

\subsection{Pre-tests and Pilot Study}

We conducted a pre-test $(n=16)$, in which subjects were presented with different excerpts of conflicts and strategies that we took from Study 1. Subjects were asked to identify: (a) the conflict content orientation ('The comments are mostly about: Animal welfare/Personal health') and (b) the type of conflict-management strategy ('Please read each comment carefully and match the statement that best describes it', where the comment was a type of conflictmanagement strategy, and the statement provided was the definition of the strategy), with $81 \%$ doing so correctly. Furthermore, $75 \%$ agreed that the scenarios were realistic (i.e. 'This could have happened on Facebook'). A subsequent pilot study $(n=20)$ of the complete survey further confirmed the manipulations, while minor wording alternations were made in accordance with respondent feedback.

\subsection{Measures}

Table 4 provides an overview of our construct measurements, based on five-point Likert scales $(1=$ strongly agree, $5=$ strongly disagree $)$. To further evaluate the psychometric properties of the two dependent variables - attitudes towards the conflict management (ATCM) and attitudes towards the organization's social responsibility (ATOSR) - we performed a confirmatory factor analysis, which revealed a well-fitting measurement model $\left(\chi^{2} / \mathrm{df}=\right.$ 22.66/10 =2.27; CFI =.99; TLI = .99; RMSEA = .05) $(\mathrm{Hu} \&$ Bentler, 1999). Composite reliability values for the management strategy and social responsibility scales were .93 and .91 
respectively, well above the recommended .7 threshold suggested by Hair et al. (2010). The average variance extracted (AVE) for the two scales was .79 and .74 , above the .5 threshold, and therefore convergent validity was deemed acceptable (Fornell \& Larcker, 1981). Discriminant validity was also acceptable, with the square root of the AVE scores for each construct (.89 and .86) being higher than the correlation between them (.53).

Since studies indicate that the perceived importance of an ethical issue (Kronrod et al., 2012), the perceived severity of the discussion (Coyne, Archer \& Eslea, 2006) and expectations of discussion moderation (McCollough, Leonard \& Manjit, 2000) have an influence on the tested variables, we also included these as control variables (see Table 4). However, when including these in our analyses, the effects remained the same.

\section{Insert Table 4 here}

\subsection{Manipulation Checks}

To assess the validity of our conflict manipulations, participants rated the conflict content orientation on an eight-point semantic differential scale ('The comments are mostly about:' 1 $=$ 'animal welfare', $8=$ 'personal health'). Realism of the conflict-management strategy ('The way WSEFC reacted is realistic; it could have happened on Facebook') was rated on a fivepoint Likert scale ( $1=$ strongly agree, $5=$ strongly disagree $)$. We used cross-tabulation employing a $\chi^{2}$ test to assess whether respondents correctly identified that the simulated $\mathrm{C} 2 \mathrm{C}$ conflict revolves around either personal health or animal welfare. The results showed that respondents correctly distinguished between the $\mathrm{C} 2 \mathrm{C}$ conflict content orientation $\chi^{2}(7,512)=$ 512.00, $p<.01$ and confirm that the respondents mostly agreed to the scenarios' realism $\chi^{2}(35$, $512)=46.15, p<.05$

\subsection{Findings}


Table 5 shows the cell means for our two dependent variables: attitudes towards the conflict management (ATCM) and attitudes towards the organization's social responsibility (ATOSR). As summarized in Table 6, we conducted two two-way analyses of variance (ANOVAs) on ATCM and ATOSR as a function of conflict content orientation and conflictmanagement strategy.

\section{Insert table 5 here}

\subsubsection{Attitude Towards Conflict Management (ATCM)}

Results revealed that from the two independent variables (conflict content orientation and conflict-management strategy), conflict-management strategy had a significant main effect $\left(F_{(5,512)}=8.43, p<.01, \eta 2=.08\right)$ on ATCM, while the main effect of content orientation was not significant $\left(F_{(1,512)}=.9, p>.05\right)$. Results of Tukey HSD post-hoc multiple comparison tests identified that participants exposed to the realignment $(M=1.73, S D=.73)$ and mobilizing $(M=2.02, S D=.9)$ strategies were significantly more positive in their ATCM compared to bolstering $(M=2.14, S D=.97)$, educating $(M=2.31, S D=1.02)$, censoring $(M=2.51, S D=1.08)$, and non-engaging $(M=2.51, S D=.98)$. There were no significant differences between any of the other conditions. We further found a significant interaction effect between conflict content orientation and conflict-management strategy $\left(F_{(5,512)}=2.42, p<.05, \eta 2=.02\right)$.

Follow-up one-way ANOVAs to test for simple effects indicated that in the self-oriented condition $\left(F_{(5,216)}=5.49, p<.01\right)$, respondents' ATCM was significantly less positive when exposed to non-engaging $(M=2.61, S D=1.09)$ as compared to mobilizing $(M=1.7, S D=.7)$ or realignment $(M=1.73, S D=.76)$. Similarly, ATCM was significantly less positive when exposed to censoring $(M=2.41, S D=1.11)$ than mobilizing and realignment. There were no significant differences between any of the other conditions. In the other-oriented condition $\left(F_{(5,296)}=5.45\right.$, $p<.01)$, ATCM was significantly less positive when exposed to non-engaging $(M=2.43$, $S D=.88)$ as compared to realignment $(M=1.73, S D=.72)$. Similarly, ATCM was also less 
positive when subjects saw the education strategy $(M=2.44, S D=1.08)$ as compared to the realignment strategy. Finally, ATCM was significantly less positive for those exposed to censoring $(M=2.57, S D=1.07)$ as compared to realignment and bolstering $(M=2.01, S D=.94)$. There were no significant differences between any of the other conditions.

\subsubsection{Attitude Towards the Organization's Social Responsibility (ATOSR)}

A two-way ANOVA revealed a significant main $\operatorname{effect}\left(F_{(5,512)}=2.45, p<.05, \eta 2=.02\right)$ from conflict-management strategy (independent variable) on ATOSR, but no significant effect from the other independent variable (conflict content orientation) on $\operatorname{ATOSR}\left(F_{(1,512)}=.00, p>.05\right)$. No significant interaction effects were identified. Follow-up post-hoc tests using Tukey HSD for the one significant main effect revealed that subjects exposed to realignment $(M=2.08$, $S D=.83$ ) perceived the organization to be more socially responsible than those exposed to censoring $(M=2.47, S D=.91)$. No significant differences were found between any of the other conditions.

\section{Insert table 6 here}

\subsection{Discussion}

Our findings help to answer our research question and are among the first to offer quantitative, experimental insights into consumers' attitudes towards a non-profit organization's conflict-management strategy in their SMFP. We address the lack of research in the for-profit and non-for profit literature, both in which authors have called for more studies to explore the effectiveness of managing consumers conflicts in the online sphere (Gensler et al., 2013; Ilhan et al., 2018; Johnson \& Lowe, 2015). In doing so, we contribute to the knowledge on the importance of understanding organizational content management on social media, as well as to show that consumer conflicts and how they are managed impact on attitudes towards an organization's social-responsibility efforts. 
It appears that, in the present context, realignment is the conflict-management strategy most likely to generate favorable user attitudes under both of the conflict content orientations (self orientation and others orientation), and most likely leads to favorable attitudes towards the organization's social responsibility efforts. In line with past research suggesting that the company requesting compliance is seen as favorable by consumers (Habel et al., 2017), our results show that users prefer this strategy when organizations moderate consumer conflicts.

In addition to realignment, we further demonstrate that mobilizing is appropriate when selforientated conflicts occur, whereas bolstering is best suited to managing other-orientated conflicts. Hence, while urging individuals to take action is effective in conflicts around issues that relate to the self, positively affirming users' comments (i.e. bolstering) is favored in moderating conflicts about issues that relate to others. Indeed, de Hooge et al. (2014) confirm that individuals are more likely to change their attitudes when they are positively reinforced. In contrast, mobilizing and bolstering do not have an effect on the fan page users' attitudes toward the organization's social-responsibility efforts. Perhaps, this reflects the view of Du, Bhattacharya and Sen (2010) and Skarmeas and Leonidou (2013), who argue that when an organization's social responsibility-related communication has an evident self-interest (i.e. mobilizing action relating to the organization's mission; encouraging behaviors that support the organization's objectives), consumers' attitudes and behaviors may remain unaffected due to their suspicion about the trustworthiness of the organizations' social responsibility motives.

\section{General Discussion}

Our knowledge of managing C2C conflicts in SMFPs is limited (Johnson \& Lowe, 2015; Labrecque et al., 2013; Matzat \& Rooks, 2014), and this is particularly true for the non-profit context (Husemann et al., 2015). This article observes and uncovers five types of strategies an NPO uses to manage $\mathrm{C} 2 \mathrm{C}$ conflicts on a Facebook fan page, and thus contributes to this under- 
researched subject. Moreover, studies so far have been limited to observational evidence of conflict-management strategies, and quantitative insights on the effects of such strategies are missing. We employ an experiment to show what types of strategy elicit the most favorable consumer attitudes toward an organization's social responsibility and the conflict-management approach itself, and to find out whether this further depends on whether a conflict is about an issue that relates to something that will benefit the consumer or others. Overall, our article is among the first to offer empirically informed guidance on conflict-management strategies for NPOs operating fan pages on social media sites.

\subsection{Implications for Research}

Our findings offer specific contributions to research knowledge. First, we show that when $\mathrm{C} 2 \mathrm{C}$ conflicts occur in non-profit fan pages, ensuring that these interactions remain civil through the use of a realignment strategy leads to enhanced outcomes for the organization. This is surprising given that NPOs operating in the social media are expected to support the right to free expression in order to nurture a popular counter-narrative (Botner et al., 2015). Nonetheless, realignment is the most favorable conflict-management strategy for NPOs to employ, irrespective of the content of the conflict (i.e. whether it revolves around issues related to the self or others). Our findings provide further empirical support that realignment generates favorable social responsibility attitudes among fan page users, complementing past studies on the general positive effects of organizations' verbalizing their perceived responsibility (BeckerOlsen, Cudmore \& Hill, 2006; Du et al., 2010).

Instead of sanctioning or suppressing fan page users' hostile $\mathrm{C} 2 \mathrm{C}$ communication, as recommended in past studies (e.g. Sibai et al., 2015), our results demonstrate that NPOs that arbitrate such interactions in a way that ensures they remain within the boundaries of civil engagement are perceived favorably. This extends past research that confirms the potent role 
of requesting compliance when managing flaming in online forums (Lee, 2005). Imposing civility as a condition for participation in non-profit SMFPs is important since the choice of conflict-management strategy has the potential not only to influence hostile interactions online, but also to prevent their spillover into offline environments. This is because realignment represents the online substitute for offline conflict management and when/if deviant behaviors are ineffectively managed online, these can translate into face-to-face settings as a result of their contagiousness (Plé \& Demangeot, 2019).

Considering that we did not observe this preferable strategy in our netnography, it can be speculated that NPOs do not use realignment because they want to encourage a wide range of opinions and views (Guo \& Saxton, 2014), rather than to appear restrictive. However, we demonstrate that users of Facebook non-profit fan pages actually favor such a strategy. Since the use of realignment may vary in relation to the behavioral standards set out by the community host (Matzat, 2009), we recommend future research to investigate such variations.

A second implication of our findings pertains to the conflict content orientations. Specifically, when self-benefit versus other-benefit content orientations are activated, two additional conflict-management strategies come into play. Contrary to Yoon, Choi and Song (2011), who suggest that individuals may perceive it as a breach of their freedom of choice, we found that mobilizing is an appropriate strategy for managing self-benefit $\mathrm{C} 2 \mathrm{C}$ conflicts. Our findings support previous studies that highlight mobilizing as one of the key functions of NPOs' fan pages (Guo \& Saxton, 2014; Lovejoy \& Saxton, 2012), and we show that it may in fact be a highly effective means of managing $\mathrm{C} 2 \mathrm{C}$ conflicts as well. When managing otherbenefit conflicts between fan page users, bolstering elicits favorable consumer attitudes. Our findings thereby offer a quantitative verification of previous research suggestions (de Hooge, et al., 2014; Schamari \& Schaefers, 2015) and proposes that bolstering is a conflictmanagement strategy whereby the organization encourages users to continue to support the 
organization's mission and related activities through affirming their opinions. Our findings support previous research which proposes that bolstering may further be linked to the concept of consumer empowerment and is effective in reducing consumer aggression (Ben-Zur \& Yagil, 2005; Labrecque et al., 2013).

A third implication from the findings is that there are two strategies less preferred by consumers: non-engaging and censoring. In Study 1, we showed that non-engaging is the most passive and frequently occurring strategy on the observed fan page. Similarly to the present non-profit context, recent research found that the most frequently utilized strategy by forprofits is non-engaging (Bacile et al., 2018; Dineva et al., 2017). Our experimental results in Study 2 are among the first to offer experimental evidence that non-engaging is perceived unfavorably by consumers, independent of the conflict content. Although it can be speculated that organizations aim to avoid alienating users through their frequent use of non-engaging (Homburg et al., 2015), non-intervention may be disliked by organizations because it can lead to undesirable outcomes for them. These include negative user attitudes towards the organization's ability to effectively moderate uncivil content and may further result in public scandals and firestorms, as demonstrated by Hauser et al. (2017). In contrast, more active strategies, specifically aimed at demanding civility when $\mathrm{C} 2 \mathrm{C}$ conflict occurs, are preferred by the users of non-profit fan pages.

Furthermore, our experimental results offer a new insight on censoring, which we found to generate unfavorable user attitudes across both conflict content orientations. Our netnography indicates that this strategy was used infrequently and exclusively in situations where consumers request it. While some past studies found that deleting user comments may be seen as impeding freedom of expression, which in turn results in damaging the organization's credibility (CohenAlmagor, 2012), others suggest that NPOs actively promote their commitment to diverse 
comments and opinions (Guo \& Saxton, 2014; Van Noort \& Willemsen, 2012), and our findings appear to support this notion.

An interesting observation with regards to the conflict content orientations is that otherbenefit content dominates the fan page, but studies show that it is not as effective (compared with self-benefit orientation) in generating favorable consumer attitudes towards organizational communication (Ye et al., 2015). This represents a nuanced difference in the mission of the NPO, that is, to reinforce desired individual behaviors. It can be speculated that self-benefit content is minimized since the topics promoted by the NPO are linked to animal welfare and rights and thus naturally the majority of $\mathrm{C} 2 \mathrm{C}$ communication will revolve around others' benefits.

\subsection{Implications for Practice}

Since fan page users' attitudes vary depending on which conflict-management strategy is used, NPOs are advised to carefully consider their choice of strategy. Our observations suggest that NPOs may be inclined not to get involved in $\mathrm{C} 2 \mathrm{C}$ conflicts. However, our findings also show that fan page users do not hold favorable attitudes towards non-engaging strategies. Our experimental results allow us to recommend some alternative strategies.

First, we suggest that NPOs ask users who are involved in a $\mathrm{C} 2 \mathrm{C}$ conflict to adjust their communication behavior or style (i.e. realignment). Our experiment shows that this will lead to favorable consumer attitudes toward the strategy itself and the organization's social responsibility. Our observations indicate that realignment may not currently be employed by NPOs, yet realignment can be a highly effective choice for managing $\mathrm{C} 2 \mathrm{C}$ conflicts. Second, we recommend that NPOs employ a mobilizing approach when the content revolves around ethical issues relevant to the self (e.g. the consequences of dairy consumption on personal health). Mobilizing not only generates favorable user attitudes toward an organization's 
conflict-management practices, but it also has the potential to encourage users to take action with regard to an ethical issue that the organization already promotes. Third, for $\mathrm{C} 2 \mathrm{C}$ conflicts that stem from ethical issues relevant to others (e.g. the consequences of dairy consumption on animal welfare), we recommend that NPOs follow a bolstering approach. Non-profit community moderators should, however, be aware that bolstering is used in the presence of consumers who are already involved with the organization's cause and consequently this strategy could further encourage like-minded consumers to voice their opinions. Fourth, we recommend that NPOs do not use censoring as a means of managing $\mathrm{C} 2 \mathrm{C}$ conflicts. Censoring does not yield favorable user attitudes towards an organization's social responsibility. Unless users request to censor content, which we observed to occasionally happen, other strategies such as realignment, mobilizing or bolstering are preferable.

\section{Conclusion, Limitations and Future Research}

This research set out to identify the strategies adopted by NPOs in managing conflicts in their SMFPs, and differences in fan page users' attitudes in regard to those strategies. The findings across both studies undertaken reveal that strategies vary across a range of active and passive approaches, but it is generally apparent that those most-often-adopted involve the organization not intervening directly in the conflict. However, findings generally with respect to users' attitudes about the different strategies suggest that a more proactive approach, involving a realignment strategy in particular, can promote a more favorable attitudinal response from consumers with regard to the organization's conflict-management practice and social responsibility efforts. In addition, there is evidence of some variation of attitudes across the two conflict orientation types we uncovered which emphasizes the desirability of different strategies and their effect on attitudes towards the organization's social responsibility. This is particularly important in a non-profit context, as perceptions about social responsibility efforts has been highlighted in the public relations literature as being critical in influencing 
stakeholders' attitudes which in turn can affect the organization's reputation, legitimacy, purchase intention, and loyalty (see Waters \& Ott, 2014).

The limitations of our research suggest avenues for further research. These are linked to the strategies adopted by the NPO and the nuances of conflict management. Our findings demonstrate the potency of realignment in generating enhanced outcomes and we recommend that future research investigates whether this is confirmed in other contexts such as advertising and political forums. We were further able to demonstrate that mobilizing is not only a novel strategy uncovered in the context of conflict management, but also an appropriate strategy for managing $\mathrm{C} 2 \mathrm{C}$ conflicts. A viable extension of our study thus will be examining the effect of different mobilization strategies as a way to diffuse conflict in SMFPs. Moreover, the overuse of a non-engaging strategy is counterintuitive for an NPO that strives to encourage communal action and is not perceived favorably by fan page users. Thus, we suggest that future studies investigate the motivations behind using non-engaging further. Another finding that is worthy of further attention by researchers is the differential impact of the two conflict orientations on user attitudes towards the management strategies and specifically how the dominance of otheroriented conflicts influences the organization's ability to encourage individual behaviors and actions.

Although Study 1 is the first to examine conflict management on an NPO's SMFP, the strategies were obtained from a single fan page and social network. This form of purposive sampling is common in exploratory research when a new phenomenon is being studied and generalization is not the primary purpose of research (Teddlie \& Yu, 2007). Future research should therefore attempt to calibrate the present findings using several SMFPs from different NPO backgrounds and hosted on additional social media channels such as Twitter or Instagram (Smith, Fischer \& Yongjian, 2012). 
Another opportunity for further research concerns the examination of the current topic in more realistic settings. Even though the manipulations were based on real-world examples, Study 2 was conducted in a controlled experimental setting. Future researchers may wish to study the phenomenon in a realistic environment (e.g. by conducting a field experiment) in order to enhance external validity. Lastly, some of the participants' demographic characteristics may have influenced their preference over certain conflict-management strategies. We studied a US sample, which necessitates the replication of the current study across different (e.g. more collectivistic) cultures. 


\section{Appendix A. Manipulation 1 - Conflict Content Orientation}

A.1 Self-benefit (personal health)-oriented organizational post and C2C conflict

WSEFC WSEFC (World Society for Ethical Food Consumption) 。

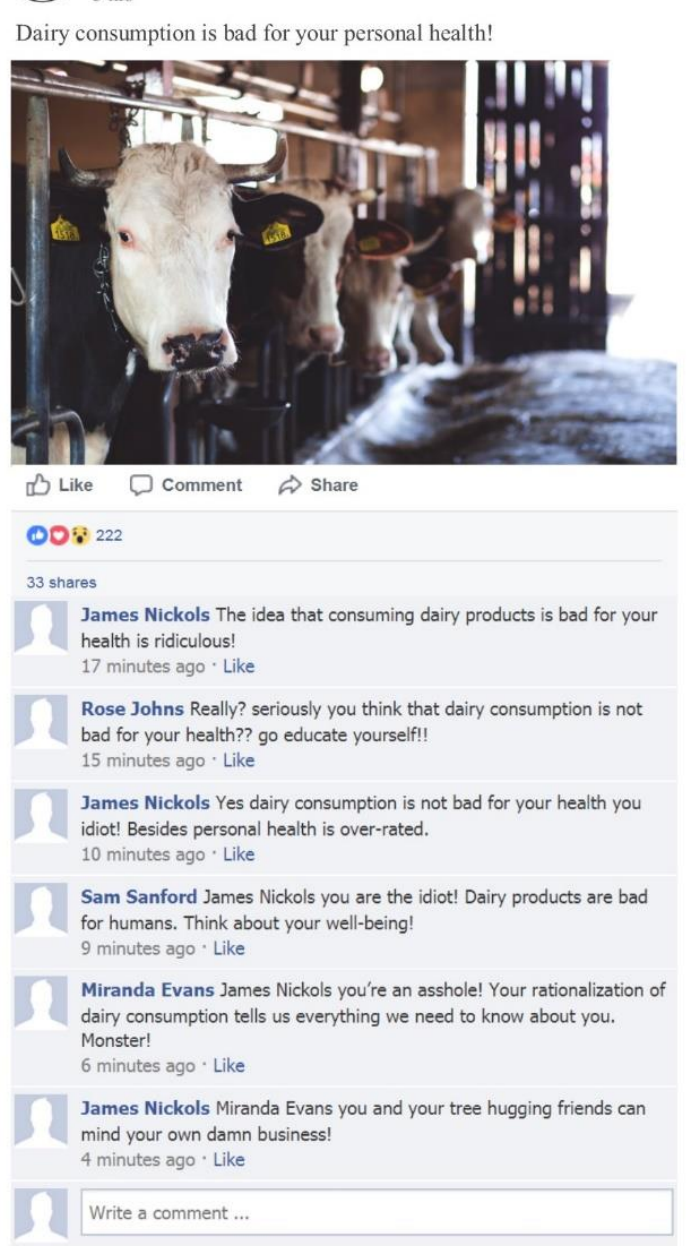

A.2 Other-benefit (animal welfare)-oriented organizational post and C2C conflict

WSEFC WSEFC (World Society for Ethical Food Consumption) $\odot$

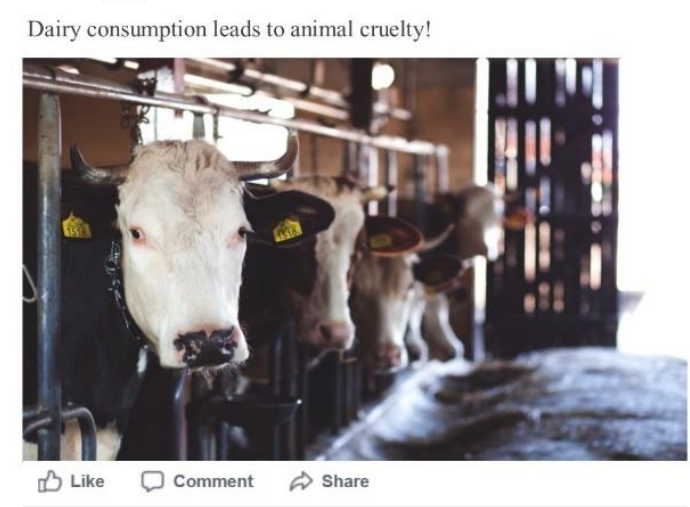

ه०: 222

33 shares

James Nickols The idea that consuming dairy products is linked to animal cruetty is ridiculous 17 minutes ago $\cdot$ Like

Rose Johns Really? seriously you think that dairy consumption is not related to animal cruelty? go educate yourself!! 15 minutes ago $\cdot$ Like

James Nickols Yes dairy consumption is not cruel you idiot! Besides animal cruelty is over-rated.

Sam Sanford James Nickols you are the idiot! Dairy products are bad for animals. Think about their well-being

Miranda Evans James Nickols you're an asshole! Your rationalization of dairy consumption tells us everything we need to know about you. 6 minutes ago · Like

James Nickols Miranda Evans you and your tree hugging friends can mind your own damn business!$$
4 \text { minutes ago · Like }
$$

Write a comment 


\section{Appendix B. Manipulation 2 - Conflict-management Strategies}

B.1 Non-engaging and Censoring

Note: Subjects exposed to the non-engaging strategy were told that the organization ignored the comments and made a new, unrelated post instead, shown below.

In the censoring condition, subjects were told that the organization deleted the comments that infringe the fan page's rules and made a new, unrelated post, shown below.

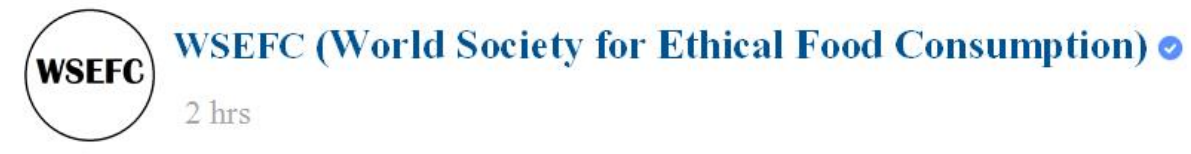

200,000 likes!!! Thank you all for your support!

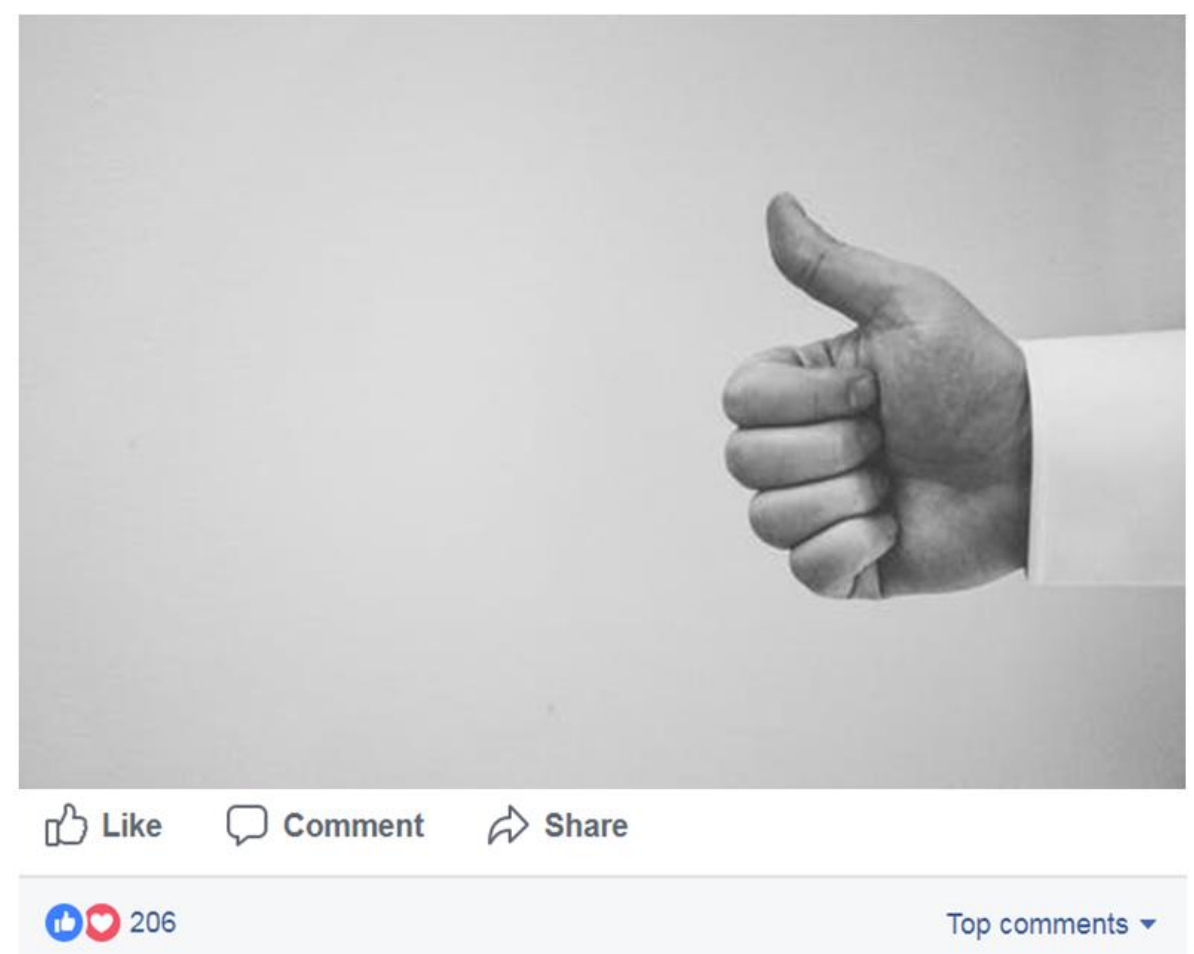


B.2 Realignment (same for both conflict content orientations)

WSEFC (World Society for Ethical Food Consumption): Swearing will not be tolerated, so can we please watch the language.

11 minutes ago · Like

Write a comment ...

B.3 Bolstering (same for both conflict content orientations)

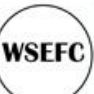

WSEFC (World Society for Ethical Food Consumption): Thank you all who support our cause!

11 minutes ago · Like

Write a comment ...

B.4 Educating (self-benefit content orientation)

WSEFC (World Society for Ethical Food Consumption): Experts

agree that as much as $90 \%$ of health problems can be related to dairy consumption.

11 minutes ago · Like

Write a comment ...

B.5 Educating (other-benefit content orientation)

\section{WSEFC (World Society for Ethical Food Consumption): Experts}

agree that as much as $90 \%$ of the dairy industry involves some form of animal cruelty.

11 minutes ago · Like

Write a comment ...

B.6 Mobilizing (self-benefit content orientation)

WSEFC (World Society for Ethical Food Consumption): Please consider dairy-free alternatives and do your health a favor!

11 minutes ago · Like

Write a comment ...

B.7 Mobilizing (other-benefit content orientation)

WSEFC (World Society for Ethical Food Consumption): Please

consider dairy-free alternatives and do the animals a favor!

11 minutes ago $\cdot$ Like

Write a comment ... 
Manuscript Tables and Figures

Table 1 Main literature on conflict management (CM) in online environments

\begin{tabular}{|c|c|c|c|c|c|c|}
\hline Author, year & $\begin{array}{l}\text { Focus of } \\
\text { investigation }\end{array}$ & CM strategies & $\begin{array}{l}\text { Type of } \\
\text { community }\end{array}$ & Context & Method & CM Theory \\
\hline $\begin{array}{l}\text { Godes et al. } \\
(2005)\end{array}$ & $\begin{array}{l}\text { The firm's } \\
\text { management of } \\
\text { (positive and } \\
\text { negative) social } \\
\text { interactions } \\
\text { between } \\
\text { consumers }\end{array}$ & $\begin{array}{l}\text { Observer, } \\
\text { moderator, } \\
\text { mediator, } \\
\text { participant }\end{array}$ & $\begin{array}{l}\text { Company-hosted, } \\
\text { Traditional online } \\
\text { community }\end{array}$ & For-profit & Conceptual & No \\
\hline Lee (2005) & $\begin{array}{l}\text { Conflict- } \\
\text { management } \\
\text { styles for } \\
\text { managing flaming }\end{array}$ & $\begin{array}{l}\text { Competitive- } \\
\text { dominating, } \\
\text { cooperative- } \\
\text { integrating and } \\
\text { avoiding }\end{array}$ & $\begin{array}{l}\text { User-hosted, } \\
\text { online forum }\end{array}$ & Feminist & $\begin{array}{l}\text { Online } \\
\text { ethnography }\end{array}$ & $\begin{array}{l}\text { Rahim (1983) } \\
\text { typology of CM } \\
\text { (integrating, } \\
\text { compromising, } \\
\text { dominating, } \\
\text { obliging, } \\
\text { avoiding) }\end{array}$ \\
\hline $\begin{array}{l}\text { Mathwick, Wiertz } \\
\text { \& De Ruyter } \\
(2008)\end{array}$ & $\begin{array}{l}\text { Relational norms } \\
\text { and social } \\
\text { structures within } \\
\text { problem-solving } \\
\text { virtual } \\
\text { communities }\end{array}$ & $\begin{array}{l}\text { Articulating } \\
\text { expectations of } \\
\text { positive } \\
\text { comments, } \\
\text { constructive } \\
\text { discussions and } \\
\text { reciprocity }\end{array}$ & $\begin{array}{l}\text { User-hosted, } \\
\text { online forum }\end{array}$ & $\begin{array}{l}\text { Peer-to-peer } \\
\text { support }\end{array}$ & $\begin{array}{l}\text { Survey, } \\
\text { netnography }\end{array}$ & No \\
\hline $\begin{array}{l}\text { Schau, Muñiz \& } \\
\text { Arnould (2009) }\end{array}$ & $\begin{array}{l}\text { Value creation } \\
\text { practices in online }\end{array}$ & $\begin{array}{l}\text { Explicit and } \\
\text { implicit governing } \\
\text { mechanisms }\end{array}$ & $\begin{array}{l}\text { Company-hosted, } \\
\text { traditional online } \\
\text { communities }\end{array}$ & For-profit & $\begin{array}{l}\text { Naturalistic } \\
\text { observations, }\end{array}$ & No \\
\hline
\end{tabular}


brand

communities

Matzat and Rooks

(2014)

\section{Styles of}

moderation in

online support

communities

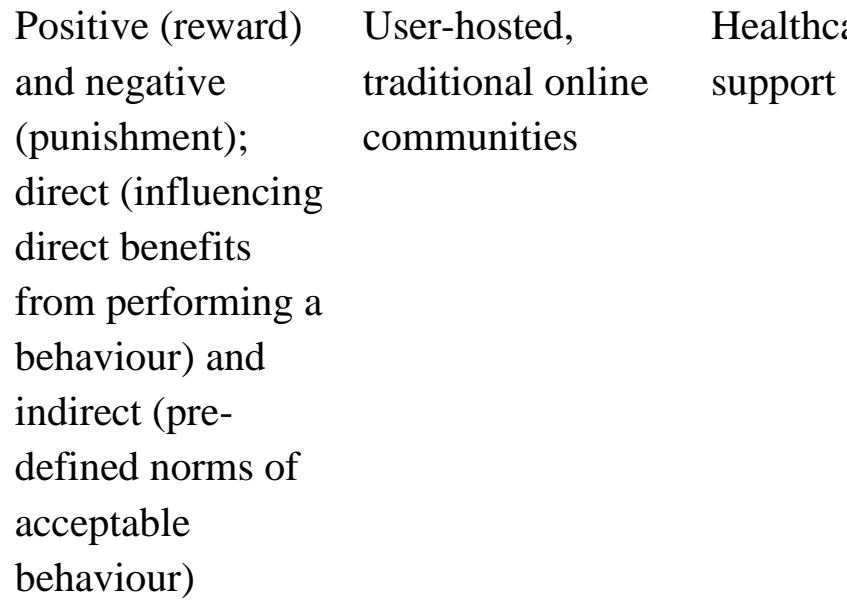

Positive (reward) and negative

(punishment);

direct (influencing

direct benefits

from performing a

behaviour) and

indirect (pre-

defined norms of

acceptable

behaviour) traditional online support communities

moderation styles

Sibai, de Valck, Farrell and Rudd (2015)

Husemann,

Ladstaetter and

Luedicke (2015)

\section{Social control and} moderation

practices in online communities initiation,

interaction

maintenance,

interaction

termination

\section{Conflict culture, Conflict} types of conflicts cultivation for

and their

management traditional online

community routine

(constructive)

conflicts, member

exclusion for

transgressive netnography,

interviews

Experiments

\section{Consumer- and}

Miscellaneous

Conceptual

No

company-hosted

\section{Consumer-hosted, Non-profit}

Netnography

No
Relational

signalling theory 
(dysfunctional)

conflicts

\begin{tabular}{|c|c|c|c|c|c|c|}
\hline $\begin{array}{l}\text { Homburg, Ehm } \\
\text { and Artz (2015) }\end{array}$ & $\begin{array}{l}\text { Managing } \\
\text { consumer } \\
\text { discussions in } \\
\text { online } \\
\text { communities }\end{array}$ & $\begin{array}{l}\text { Passive and active } \\
\text { moderation }\end{array}$ & $\begin{array}{l}\text { Company-hosted, } \\
\text { online forums }\end{array}$ & For-profit & $\begin{array}{l}\text { Sentiment } \\
\text { analysis }\end{array}$ & No \\
\hline $\begin{array}{l}\text { Dineva, Breitsohl } \\
\text { and Garrod (2017) }\end{array}$ & $\begin{array}{l}\text { Conflict- } \\
\text { management } \\
\text { strategies in } \\
\text { SMFPs }\end{array}$ & $\begin{array}{l}\text { Non-engaging, } \\
\text { Censoring } \\
\text { Bolstering, } \\
\text { Pacifying, } \\
\text { Informing }\end{array}$ & $\begin{array}{l}\text { Company-hosted, } \\
\text { social media- } \\
\text { based } \\
\text { communities }\end{array}$ & For-profit & Direct observation & No \\
\hline $\begin{array}{l}\text { Hauser, Hautz, } \\
\text { Hutter and Fuller } \\
(2017)\end{array}$ & $\begin{array}{l}\text { Conflict } \\
\text { management of } \\
\text { public scandals } \\
\text { and firestorms }\end{array}$ & $\begin{array}{l}\text { A range of } \\
\text { cooperative and } \\
\text { assertive } \\
\text { strategies - } \\
\text { accommodating, } \\
\text { collaborating, } \\
\text { competing, } \\
\text { avoiding }\end{array}$ & $\begin{array}{l}\text { Company-hosted, } \\
\text { social media- } \\
\text { based } \\
\text { communities }\end{array}$ & For-profit & $\begin{array}{l}\text { Agent-based } \\
\text { modelling }\end{array}$ & $\begin{array}{l}\text { Blake and Mouton } \\
\text { (1964) CM } \\
\text { typology }\end{array}$ \\
\hline $\begin{array}{l}\text { Bacile, Wolter, } \\
\text { Allen and Xu } \\
\text { (2018) }\end{array}$ & $\begin{array}{l}\text { The impact of } \\
\text { consumer } \\
\text { incivility in } \\
\text { service recovery } \\
\text { on social media } \\
\text { channels }\end{array}$ & Non-engaging & $\begin{array}{l}\text { Company-hosted, } \\
\text { social media- } \\
\text { based }\end{array}$ & For profit & $\begin{array}{l}\text { Netnography, } \\
\text { experiment }\end{array}$ & No \\
\hline
\end{tabular}


Table 2 Linguistic characteristics of negative (counterproductive) C2C conflict

\begin{tabular}{|c|c|c|c|}
\hline $\begin{array}{l}\text { Linguistic } \\
\text { characteristic }\end{array}$ & Definition & References & Examples \\
\hline Two-way exchange & $\begin{array}{l}\text { A two-way episode } \\
\text { where the originator } \\
\text { (aggressor/victim) } \\
\text { looks for/receives a } \\
\text { verbal response from } \\
\text { another person. }\end{array}$ & $\begin{array}{l}\text { Breitsohl et al. } \\
\text { (2018) }\end{array}$ & $\begin{array}{l}\text { "I have zero respect for } \\
\text { the Asian culture. They } \\
\text { are fucking sick." } \\
\text { "not all asian do that } \\
\text { you bitch" }\end{array}$ \\
\hline Profanity & $\begin{array}{l}\text { The use of obscene } \\
\text { words and language. }\end{array}$ & $\begin{array}{l}\text { Al-garadi et al. } \\
(2016) \text {; Wang et } \\
\text { al. (2014) }\end{array}$ & $\begin{array}{l}\text { "fucking", "bullshit", } \\
\text { "cunt", "asshole", } \\
\text { "racist fucks" }\end{array}$ \\
\hline $\begin{array}{l}\text { Rude or insulting } \\
\text { diatribe }\end{array}$ & $\begin{array}{l}\text { (Vicious) personal } \\
\text { attacks towards a } \\
\text { person who posts a } \\
\text { comment. }\end{array}$ & $\begin{array}{l}\text { Bourgonje et } \\
\text { al., (2017); } \\
\text { Bogolyubova et } \\
\text { al. (2018) }\end{array}$ & $\begin{array}{l}\text { "despicable excuse for } \\
\text { human being", "are you } \\
\text { an ass?", } \\
\text { "your an idiot", "you } \\
\text { sure are special...high } \\
\text { school drop out", "you } \\
\text { make yourself look like } \\
\text { a fool" }\end{array}$ \\
\hline $\begin{array}{l}\text { Emoticons and } \\
\text { acronyms }\end{array}$ & $\begin{array}{l}\text { The use of emoticons } \\
\text { and acronyms to } \\
\text { reinforce the content } \\
\text { intensity. }\end{array}$ & $\begin{array}{l}\text { Runions et al. } \\
\text { (2013) }\end{array}$ & $\begin{array}{l}\text { middle finger emoji, } \\
\text { face with rolling eyes } \\
\text { emoji; } \\
\text { "Ffs" ("for fuck's } \\
\text { sake"), "stfu" ("shut the } \\
\text { fuck up"), "wtf" ("what } \\
\text { the fuck"), "af" ("as } \\
\text { fuck") }\end{array}$ \\
\hline $\begin{array}{l}\text { Capitalized words } \\
\text { and sentences }\end{array}$ & $\begin{array}{l}\text { The deliberate use of } \\
\text { capitalized } \\
\text { words/sentences to } \\
\text { emphasize a point/ } \\
\text { express the emotion of } \\
\text { anger. }\end{array}$ & $\begin{array}{l}\text { Byron \& } \\
\text { Baldridge } \\
\text { (2005); Lloyd et } \\
\text { al. (2010) }\end{array}$ & $\begin{array}{l}\text { "For someone that's so } \\
\text { patriotic you know } \\
\text { NOTHING about } \\
\text { freedom of speech } \\
\text { DOUCHEBAG", } \\
\text { "SHITTY VEGAN } \\
\text { PROPAGANDA } \\
\text { PAGE" }\end{array}$ \\
\hline $\begin{array}{l}\text { Multiple } \\
\text { punctuation marks }\end{array}$ & $\begin{array}{l}\text { The deliberate use of } \\
\text { multiple punctuation } \\
\text { marks to express an } \\
\text { intense emotion. }\end{array}$ & $\begin{array}{l}\text { Byron \& } \\
\text { Baldridge } \\
(2005) ; \text { Lloyd et } \\
\text { al. (2010) }\end{array}$ & $\begin{array}{l}\text { “"!!!”, ‘???”, “"?!?!”, } \\
\text { "...." }\end{array}$ \\
\hline
\end{tabular}


Table 3 Conflict-management strategies, conflict content types and sample comments

\begin{tabular}{|c|c|c|c|c|c|}
\hline & Codes & Themes & Observed & Definition & Excerpt \\
\hline \multirow[t]{9}{*}{$\begin{array}{l}\text { Conflict- } \\
\text { management } \\
\text { strategy }\end{array}$} & $\begin{array}{l}\text { Not intervening in } \\
\text { the conflict }\end{array}$ & Non-engaging & 265 & $\begin{array}{l}\text { The organization does not } \\
\text { take any action to moderate a } \\
\text { conflict. }\end{array}$ & \\
\hline & $\begin{array}{l}\text { Avoiding engaging } \\
\text { in the conflict }\end{array}$ & & & & \\
\hline & Missing comments & Censoring & 2 & $\begin{array}{l}\text { The organization } \\
\text { permanently removes } \\
\text { consumer comments. }\end{array}$ & [comment was removed] \\
\hline & $\begin{array}{l}\text { Thanks cause } \\
\text { supporter(s) }\end{array}$ & Bolstering & 14 & $\begin{array}{l}\text { The organization affirms a } \\
\text { consumer comment. }\end{array}$ & $\begin{array}{l}\text { "Thank you for choosing compassion! } \\
\text { (heart emoji) \#FriendsNotFood } \\
\text { \#TheYearOfVegan" }\end{array}$ \\
\hline & $\begin{array}{l}\text { Agrees with cause } \\
\text { supporter(s) }\end{array}$ & & & & $\begin{array}{l}\text { "@isa thanks for explaining supply \& } \\
\text { demand. (winking face emoji)” }\end{array}$ \\
\hline & $\begin{array}{l}\text { Further clarification } \\
\text { about an issue } \\
\text { causing the conflict }\end{array}$ & Educating & 21 & $\begin{array}{l}\text { The organization provides } \\
\text { educational information } \\
\text { about an ethical issue. }\end{array}$ & $\begin{array}{l}\text { "Zoos claim to provide educational } \\
\text { opportunities, but most visitors spend } \\
\text { only a few minutes at each display, } \\
\text { seeking entertainment rather than }\end{array}$ \\
\hline & $\begin{array}{l}\text { Explaining an issue } \\
\text { to conflicting }\end{array}$ & & & & enlightment [sic]." \\
\hline & parties & & & & $\begin{array}{l}\text { "Keeping animals in cages does } \\
\text { nothing to foster respect for animals }\end{array}$ \\
\hline & $\begin{array}{l}\text { Providing additional } \\
\text { information about } \\
\text { an issue }\end{array}$ & & & & $\begin{array}{l}\text { since all children learn is that animals } \\
\text { will spend their lives behind bars for } \\
\text { people's fleeting distraction and } \\
\text { amusement." }\end{array}$ \\
\hline
\end{tabular}




\begin{tabular}{|c|c|c|c|c|c|}
\hline & $\begin{array}{l}\text { An appeal to take } \\
\text { action } \\
\text { Urging conflicting } \\
\text { parties to change } \\
\text { their behavior }\end{array}$ & Mobilizing & 30 & $\begin{array}{l}\text { The organization urges } \\
\text { consumers to take action } \\
\text { towards an ethical issue. }\end{array}$ & $\begin{array}{l}\text { "Please tell everyone you know to go } \\
\text { vegan to help stop this! } \\
\text { http://www.peta.org/living/food/free- } \\
\text { vegan-starter-kit/" } \\
\text { "Unfortunately, a majority of dairy } \\
\text { farms use practices like the ones seen } \\
\text { in this video. Please consider ditching } \\
\text { dairy and going vegan: } \\
\text { http://features.peta.org/how-to-go- } \\
\text { vegan/" }\end{array}$ \\
\hline \multirow[t]{2}{*}{$\begin{array}{l}\text { Conflict } \\
\text { content }\end{array}$} & $\begin{array}{l}\text { Vegan lifestyle as a } \\
\text { personal choice } \\
\text { Implications of } \\
\text { vegan diet on } \\
\text { personal health } \\
\text { Testing on } \\
\text { animals/using } \\
\text { animals for } \\
\text { entertainment for } \\
\text { the benefit of } \\
\text { humans }\end{array}$ & Self-oriented & 29 & $\begin{array}{l}\text { Conflict content revolving } \\
\text { around issues related to the } \\
\text { self. }\end{array}$ & $\begin{array}{l}\text { "We have EVOLVED!!! We can live } \\
\text { and live WELL on plant-based protein } \\
\text { sources!" } \\
\text { "If you or your loved one gets cancer, } \\
\text { you'll expect the best cancer chemo } \\
\text { drugs. How do you think they came up } \\
\text { w/ these drugs?? Say we ban animal } \\
\text { trials, ok, so how do we test drugs } \\
\text { then?" } \\
\text { "Vegan diet isn't for everyone } \\
\text { especially those who need protein like } \\
\text { me it has shown that } 90 \%+\text { vegans are } \\
\text { nutrients deficient in a way" }\end{array}$ \\
\hline & $\begin{array}{l}\text { Implications of } \\
\text { personal/collective } \\
\text { consumption }\end{array}$ & Other-oriented & 144 & $\begin{array}{l}\text { Conflict content revolving } \\
\text { around issues related to } \\
\text { others. }\end{array}$ & $\begin{array}{l}\text { "Yeah I'm still gonna eat it..while I } \\
\text { wish animals were treated better and } \\
\text { killed more humanely.. Animals killing }\end{array}$ \\
\hline
\end{tabular}


choices on animal

welfare/rights other animals is a fact of life. Humans

are no different."

"You do realize that animals don't have souls right? They are magnificent creatures. One of the great pieces of Gods creation. However, they are not equal to humans and they do not have souls."

"Oh for goodness sake...some of these comments must me a joke right? You think that stealing dolphins from their homes and subjecting them to short lives of misery is justified to help a child that had a few minutes of "connection"?"

"@ David come on, just because it's lawful and has a "Kennel Club" stamp of approval doesn't make it right. They may be looked after and treated well but ultimately the puppies are being breed for profit." 
Table 4 Measurement Constructs

\begin{tabular}{ll}
\hline Construct & Items \\
\hline
\end{tabular}

Attitude towards the conflictmanagement strategy ( $\alpha=.94$; from Nan \& Heo, 2007)

Attitudes towards the organization's social responsibility ( $\alpha=.90$; from Wagner, Lutz \& Weitz, 2009)

Perceived importance of an ethical issue (from Kronrod et al., 2012)

Perceived severity of the discussion (from Coyne et al., 2006)

Expectations of discussion moderation (from McCollough et al., 2000)
The organization's reaction is fair.

The organization's reaction is justified.

The organization's reaction is appropriate.

The organization's reaction is acceptable.

WSEFC is a socially responsible organization. WSEFC is concerned to improve the wellbeing of others.

WSEFC follows high ethical standards.

Animal cruelty is important to me.

My personal health is important to me.

I think that comments like these are upsetting.

I expect that WSEFC will take some action to moderate similar discussions.

Table 5 Cell means by experimental condition

\begin{tabular}{|c|c|c|c|c|c|}
\hline \multirow{2}{*}{$\begin{array}{l}\text { Conflict- } \\
\text { management } \\
\text { Strategy }\end{array}$} & \multirow[b]{2}{*}{ Conflict content } & \multicolumn{2}{|c|}{ ATCM } & \multicolumn{2}{|c|}{ ATOSR } \\
\hline & & Mean & Std. Dev. & Mean & Std. Dev. \\
\hline \multirow[t]{2}{*}{ Non-engaging } & Self-oriented & 2.61 & 1.09 & 2.35 & 1.07 \\
\hline & Other-oriented & 2.43 & .88 & 2.16 & .89 \\
\hline \multirow[t]{2}{*}{ Censoring } & Self-oriented & 2.41 & 1.11 & 2.48 & 1.00 \\
\hline & Other-oriented & 2.57 & 1.07 & 2.46 & .87 \\
\hline \multirow[t]{2}{*}{ Mobilizing } & Self-oriented & 1.7 & .7 & 1.89 & .66 \\
\hline & Other-oriented & 2.26 & .95 & 2.34 & .91 \\
\hline \multirow[t]{2}{*}{ Realignment } & Self-oriented & 1.73 & .76 & 2.09 & .9 \\
\hline & Other-oriented & 1.73 & .72 & 2.07 & .78 \\
\hline \multirow[t]{2}{*}{ Bolstering } & Self-oriented & 2.35 & .98 & 2.47 & .8 \\
\hline & Other-oriented & 2.01 & .94 & 2.25 & .83 \\
\hline
\end{tabular}




$\begin{array}{llrrrr}\text { Educating } & \text { Self-oriented } & 2.16 & .95 & 2.3 & .84 \\ & \text { Other-oriented } & 2.44 & 1.08 & 2.33 & .69\end{array}$

Note. All items were measured using Likert-type scales ranging from $1=$ Strongly agree to $5=$ Strongly disagree

Table 6 Summary results of two-way ANOVAs

\begin{tabular}{lllll}
\hline Dependent variable & Df & $\begin{array}{l}\text { Mean } \\
\text { square }\end{array}$ & $F$ & Sig. \\
\hline ATCM & 1 & .81 & .9 & n.s. \\
Conflict content & 5 & 7.58 & 8.43 & $<.01$ \\
Conflict management & 5 & 2.18 & 2.42 & $<.05$ \\
Conflict management x conflict content & 500 & .9 & & \\
Error & 512 & & & \\
Total & & & & \\
& & & .00 & n.s. \\
ATOSR & 1 & .00 & 2.45 & $<.05$ \\
Conflict content & 5 & 1.8 & 1.58 & n.s. \\
Conflict management & 5 & 1.16 & & \\
Conflict management x conflict content & 500 & .74 & & \\
Error & 512 & & & \\
Total & & & & \\
\hline
\end{tabular}

Figure $1 \mathrm{C} 2 \mathrm{C}$ conflict excerpt

Tom Jacobs Humans are simply disgusting cruel animals, the only truly thoughtless 'cruel' animal. Vegan 4 life (:) (:) (:)

50 minutes ago · Like

Chris Zaborsky Well since your human and I'm sure you were fed meat as a child and your parents. You should hate yourself 48 minutes ago ' Like

Samantha Jones Bit of a jump there @Chris

44 minutes ago ' Like

Tom Jacobs I...do and I wish my parents knew how traumatic eating animals was for me as a child. I always loved animals And I was very sensitive to suffering....Wish I could go back as a kid, knowing what I know. I've been vegan for 25 years, but wish it was my whole existence O

40 minutes ago · Like

Adam Payne @Tom has made the choice to be vegan now as an adult when he understands what is happening. He should be proud of himself. He most defiantly should not hate himself"

36 minutes ago · Like

Tom Jacobs Thanks @Adam Payne (:)

31 minutes ago - Like

Christian Mawson @Chris Zaborsky your an idiot

27 minutes ago · Like

PETA (People for the Ethical Treatment of Animals) Thank you for making a difference for animals by living a vegan lifestyle $\bigcirc$

25 minutes ago · Like

Write a comment ... 
Figure 2 Conflict-management research gap

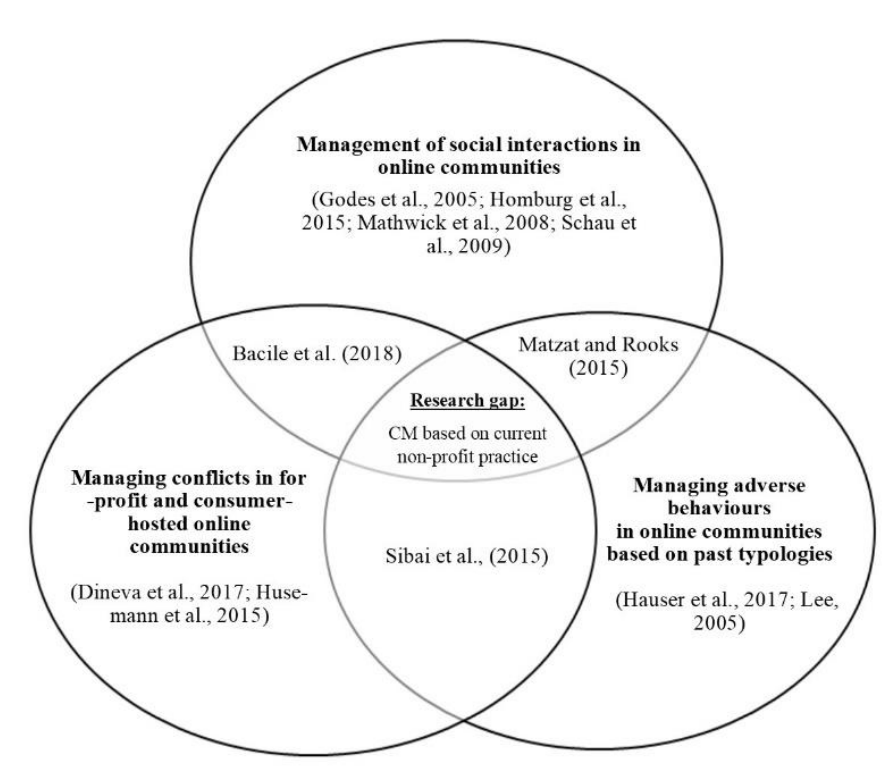

Figure 3 Study 1 Research procedure

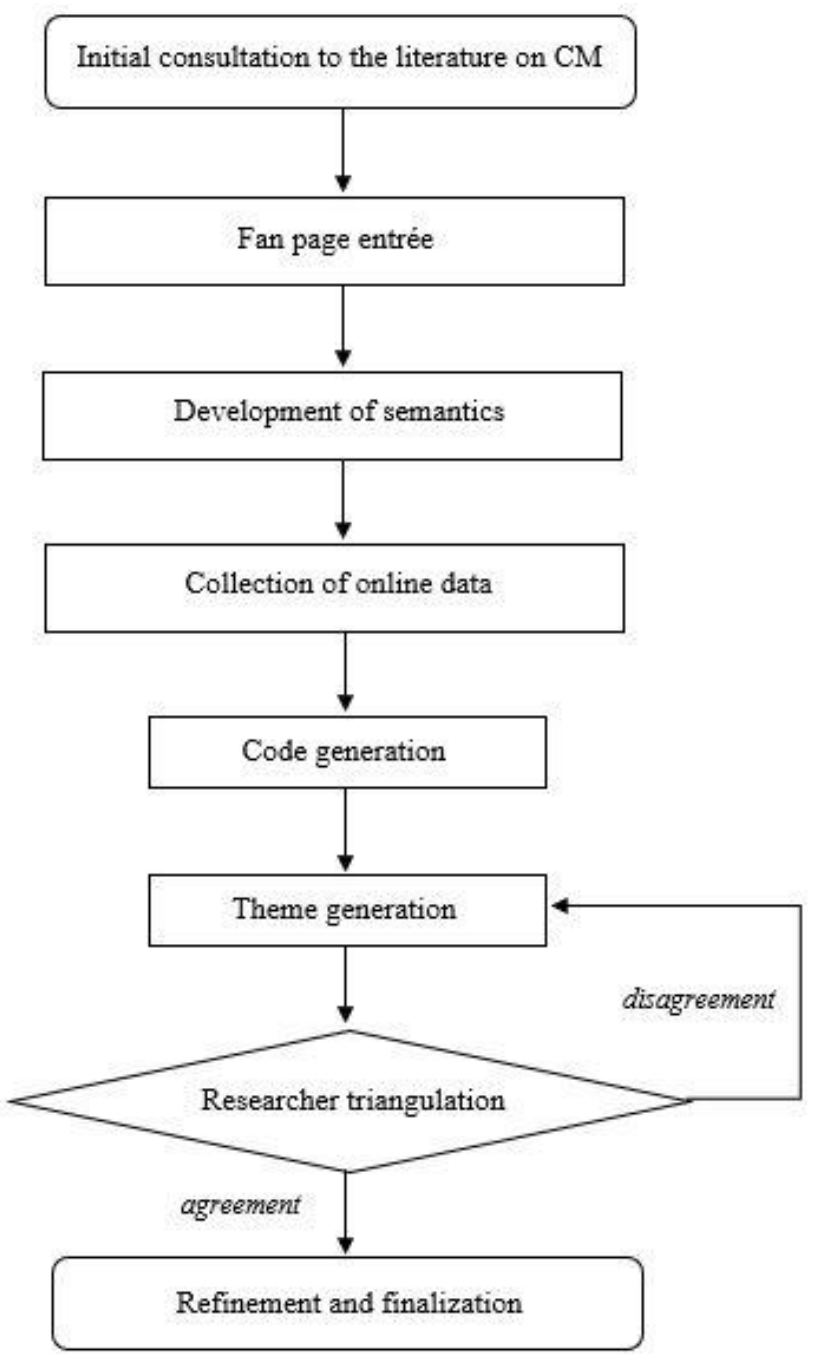




\section{References}

Aaker, Jennifer, Kathleen D. Vohs, and Cassie Mogilner (2010), "Nonprofits are seen as warm and for-profits as competent: Firm stereotypes matter," Journal of Consumer Research, 37, 2, 224237, doi: $10.1086 / 651566$

Al-garadi, Mohammed Ali, Kasturi Dewi Varathan, and Sri Devi Ravana (2016), "Cybercrime detection in online communications: The experimental case of cyberbullying detection in the Twitter network," Computers in Human Behavior, 63, 433-443, doi: $10.1016 /$ j.chb.2016.05.051

Amatulli, Cesare, Matteo De Angelis, Alessandro M. Peluso, Isabella Soscia, and Gianluigi Guido (2017), "The effect of negative message framing on green consumption: An investigation of the role of shame," Journal of Business Ethics, 157, 1-22, doi:10.1007/s10551-017-3644-X

Anderson, Ashley A., Dominique Brossard, Dietram A. Scheufele, Michael A. Xenos, and Peter Ladwig (2014), "The "nasty effect:" Online incivility and risk perceptions of emerging technologies," Journal of Computer-Mediated Communication, 19, 3, 373-387, doi:10.1111/jec4.12009

Bacile, Todd J., Jeremy S. Wolter, Alexis M. Allen, and Pei Xu (2018), "The effects of online incivility and consumer-to-consumer interactional justice on complainants, observers, and service providers during social media service recovery," Journal of Interactive Marketing, 44, 60-81, doi:10.1016/j.intmar.2018.04.002

Barcelos, Renato Hübner, Danilo C. Dantas, and Sylvain Sénécal (2018), "Watch your tone: How a brand's tone of voice on social media influences consumer responses," Journal of Interactive Marketing, 41, 60-80, doi:10.1016/j.intmar.2017.10.001

Becker-Olsen, Karen L., B. Andrew Cudmore, and Ronald Paul Hill (2006), "The impact of perceived corporate social responsibility on consumer behaviour," Journal of Business Research, 59, 1, 46-53, doi:10.1016/j.jbusres.2005.01.001

Ben-Zur, Hasida, and Dana Yagil (2005), "The relationship between empowerment, aggressive behaviours of customers, coping, and burnout," European Journal of Work and Organizational Psychology, 14, 1, 81-99, doi:10.1080/13594320444000281

Bernritter, Stefan F., Peeter WJ Verlegh, and Edith G. Smit (2016), "Why nonprofits are easier to endorse on social media: The roles of warmth and brand symbolism," Journal of Interactive Marketing, 33, 27-42, doi:10.1016/j.intmar.2015.10.002

Blake, Robert Rogers, and Jane Srygley Mouton (1964), The managerial grid, Houston: Gulf Publishing.

Bogolyubova, Olga, Polina Panicheva, Roman Tikhonov, Viktor Ivanov, and Yanina Ledovaya (2018), "Dark personalities on Facebook: Harmful online behaviors and language," Computers in Human Behavior, 78, 151-159, doi:10.1016/j.chb.2017.09.032

Botner, Keith A., Arul Mishra, and Himanshu Mishra (2015), "What's in a message? The longitudinal influence of a supportive versus combative orientation on the performance of nonprofits," Journal of Marketing Research, 52, 1, 39-55, doi:10.1509/jmr.13.0211

Bourgonje, Peter, Julian Moreno-Schneider, Ankit Srivastava, and Georg Rehm (2017), “Automatic classification of abusive language and personal attacks in various forms of online communication," International Conference of the German Society for Computational Linguistics and Language Technology (pp. 180-191). Springer, Cham. 
Braun, Virginia, and Victoria Clarke (2006), "Using thematic analysis in psychology," Qualitative Research in Psychology, 3, 2, 77-101, doi:10.1191/1478088706qp063oa

Braun, Virginia, and Victoria Clarke (2014), "Thematic analysis". In H. Cooper (Ed.), APA handbook of research methods in psychology (Vol. 2, pp. 57-71). Washington, DC: American Psychological Association.

Bray, Jeffery, Nick Johns, and David Kilburn (2011), “An exploratory study into the factors impeding ethical consumption," Journal of Business Ethics, 98, 4, 597-608, doi: $10.1007 / \mathrm{s} 10551-010-0640-9$

Breitsohl, Jan, Holger Roschk, and Christina Feyertag (2018), “Consumer brand bullying behaviour in online communities of service firms," In, Bruhn, Manfred and Hadwich, Karsten: Service business development (pp. 289-312). Springer Gabler, Wiesbaden.

Buckels, Erin E., Paul D. Trapnell, and Delroy L. Paulhus (2014), “Trolls just want to have fun," Personality and Individual Differences, 67, 97-102, doi:10.1016/j.paid.2014.01.016

Burke, Paul F., Christine Eckert, and Stacey Davis (2014), "Segmenting consumers' reasons for and against ethical consumption," European Journal of Marketing, 48, 11/12, 2237-2261, doi:10.1108/EJM-06-2013-0294

Byron, Kristin, and David C. Baldridge (2005), "Toward a model of nonverbal cues and emotion in email," Academy of Management Proceedings, B1-B6, doi:10.5465/ambpp.2005.18781269

Carrington, Michal J., Benjamin A. Neville, and Gregory J. Whitwell (2014), "Lost in translation: Exploring the ethical consumer intention-behavior gap," Journal of Business Research, 67, 1, 2759-2767, doi:10.1016/j.jbusres.2012.09.022

Chan, Kimmy Wa, and Stella Yiyan Li (2010), "Understanding consumer-to-consumer interactions in virtual communities: The salience of reciprocity," Journal of Business Research, 63, 9-10, 1033-1040, doi:10.1016/i.jbusres.2008.08.009

Chen, Katherine K., Howard Lune, and Edward L. Queen (2013), "How values shape and are shaped by nonprofit and voluntary organizations: The current state of the field," Nonprofit and Voluntary Sector Quarterly, 42, 5, 856-885, doi:10.1177/0899764013480273

Cohen-Almagor, Raphael (2012), "Freedom of expression, internet responsibility, and business ethics: The Yahoo! saga and its implications," Journal of Business Ethics, 106, 3, 353-365, doi: $10.1007 / \mathrm{s} 10551-011-1001-\mathrm{Z}$

Coyne, Sarah M., John Archer, and Mike Eslea (2006), ““"We're not friends anymore! Unless...”: The frequency and harmfulness of indirect, relational, and social aggression," Aggressive Behavior: Official Journal of the International Society for Research on Aggression, 32, 4, 294307, doi: $10.1002 / a b .20126$

De Almeida, Stefânia Ordovás, Utpal M. Dholakia, José Mauro C. Hernandez, and José Afonso Mazzon (2014), "The mixed effects of participant diversity and expressive freedom in online peer-to-peer problem solving communities," Journal of Interactive Marketing, 28, 3, 196-209. doi:10.1016/j.intmar.2014.02.003

De Hooge, Ilona E., Peeter WJ Verlegh, and Stefanie C. Tzioti (2014), "Emotions in advice taking: The roles of agency and valence," Journal of Behavioral Decision Making, 27, 3, 246-258, doi: $10.1002 / \mathrm{bdm} .1801$ 
de la Peña, Alicia, Bernardo Amezcua, and César Sepúlveda (2018), "Cause-brand community: Toward consumer citizenship," Journal of Nonprofit \& Public Sector Marketing, 30, 1, 1-36, doi:10.1080/10495142.2017.1326334

De Valck, Kristine (2007), "The war of the e-tribes: Online conflicts and communal consumption," In Cova, Bernard, Kozinets, V. Robert and Shankar, Avi (Eds.), Consumer tribes (pp. 260275). Oxford: Elsevier.

Dineva, Denitsa Petrova, Jan Christian Breitsohl, and Brian Garrod (2017), "Corporate conflict management on social media brand fan pages," Journal of Marketing Management, 33, 9/10, 679-698, doi: $10.1080 / 0267257 X .2017 .1329225$

Du, Shuili, Chitrabhan B. Bhattacharya, and Sankar Sen (2010), "Maximizing business returns to corporate social responsibility (CSR): The role of CSR communication," International Journal of Management Reviews, 12, 1, 8-19, doi:10.1111/j.1468-2370.2009.00276.x

Ensari, Nurcan, Camden-Anders, Sherry, and Schlaerth, Andrea (2015), "Constructive management and resolution of conflict," In Friedman, Howard (Ed.), Encyclopedia of mental health (Vol. 1, pp. 340-349). Amsterdam: Elsevier.

Ertimur, Burçak, and Mary C. Gilly (2012), "So whaddya think? Consumers create ads and other consumers critique them," Journal of Interactive Marketing, 26, 3, 115-130, doi:10.1016/j.intmar.2011.10.002

Ewing, Michael T., Peter E. Wagstaff, and Irene H. Powell (2013), "Brand rivalry and community conflict," Journal of Business Research, 66, 1, 4-12, doi:10.1016/j.jbusres.2011.07.017

Felix, Reto, Philipp A. Rauschnabel, and Chris Hinsch (2017), "Elements of strategic social media marketing: A holistic framework," Journal of Business Research,70, 118-126, doi:10.1016/j.jbusres.2016.05.001

Fisher, Robert J., Mark Vandenbosch, and Kersi D. Antia (2008), “An empathy-helping perspective on consumers' responses to fund-raising appeals," Journal of Consumer Research, 35, 3, 519531, doi: $10.1086 / 586909$

Fisk, Ray, Stephen Grove, Lloyd C. Harris, Dominique A. Keeffe, Kate L. Daunt (née Reynolds), Rebekah Russell- Bennett and Jochen Wirtz (2010), "Customers behaving badly: A state of the art review, research agenda and implications for practitioners," Journal of Services Marketing, 24, 6, 417-429, doi:10.1108/08876041011072537

Fornell, Claes, and David F. Larcker (1981), "Evaluating structural equation models with unobservable variables and measurement error," Journal of Marketing Research, 18, 1, 39-50, doi: $\underline{3151312}$

Freestone, Oliver M., and Peter J. McGoldrick (2008), "Motivations of the ethical consumer," Journal of Business Ethics, 79, 4, 445-467, doi:10.1007/s10551-007-9409-1

Fusch, Patricia I., and Lawrence R. Ness (2015), "Are we there yet? Data saturation in qualitative research," The Qualitative Report, 20, 9, 1408-1416. Available at: https://nsuworks.nova.edu/tqr/vol20/iss9/3

Gebauer, Johannes, Johann Füller, and Roland Pezzei (2013), "The dark and the bright side of cocreation: Triggers of member behavior in online innovation communities," Journal of Business Research, 66, 9, 1516-1527, doi:10.1016/j.jbusres.2012.09.013 
Gensler, Sonja, Franziska Völckner, Yuping Liu-Thompkins, and Caroline Wiertz (2013), "Managing brands in the social media environment," Journal of Interactive Marketing, 27, 4, 242-256, doi:10.1016/j.intmar.2013.09.004

Godes, David, Dina Mayzlin, Yubo Chen, Sanjiv Das, Chrysanthos Dellarocas, Bruce Pfeiffer, Barak Libai, Subrata Sen, Mengze Shi, and Peeter Verlegh (2005), "The firm's management of social interactions," Marketing Letters, 16, 3-4, 415-428, doi:10.1007/s11002-005-5902-4

Green, Todd, and John Peloza (2014), "Finding the right shade of green: The effect of advertising appeal type on environmentally friendly consumption," Journal of Advertising, 43, 2, 128-141, doi: $\underline{10.1080 / 00913367.2013 .834805}$

Gretry, Anaïs, Csilla Horváth, Nina Belei, and Allard CR van Riel (2017). ““'Don't pretend to be my friend!" When an informal brand communication style backfires on social media," Journal of Business Research, 74, 77-89, doi:10.1016/j.jbusres.2017.01.012

Guo, Chao, and Gregory D. Saxton (2014), "Tweeting social change: How social media are changing nonprofit advocacy," Nonprofit and Voluntary Sector Quarterly, 43, 1, 57-79, doi: $10.1177 / 0899764012471585$

Habel, Johannes, Sascha Alavi, and Doreén Pick (2017), "When serving customers includes correcting them: Understanding the ambivalent effects of enforcing service rules," International Journal of Research in Marketing, 34, 4, 919-941, doi:10.1016/j.ijresmar.2017.09.002

Habibi, Mohammad Reza, Michel Laroche, and Marie-Odile Richard (2014) "The roles of brand community and community engagement in building brand trust on social media," Computers in Human Behavior, 37, 152-161, doi:10.1016/j.chb.2014.04.016

Hair, Joseph F., William C. Black, Barry J. Babin, and Rolph E. Anderson (2010), Multivariate data analysis. Pearson, NJ: Pearson Education.

Hassay, Derek N., and John Peloza (2009), "Building the charity brand community," Journal of Nonprofit \& Public Sector Marketing, 21, 1, 24-55, doi:10.1080/10495140802111927

Hauser, Florian, Julia Hautz, Katja Hutter, and Johann Füller (2017), "Firestorms: Modeling conflict diffusion and management strategies in online communities," The Journal of Strategic Information Systems, 26, 4, 285-321, doi:10.1016/j.jsis.2017.01.002

Homburg, Christian, Laura Ehm, and Martin Artz (2015), "Measuring and managing consumer sentiment in an online community environment," Journal of Marketing Research, 52, 5, 629641, doi:10.1509/jmr.11.0448

$\mathrm{Hu}, \mathrm{Li}$ - tze, and Peter M. Bentler (1999), "Cutoff criteria for fit indexes in covariance structure analysis: Conventional criteria versus new alternatives," Structural Equation Modeling: A Multidisciplinary Journal, 6, 1, 1-55, doi:10.1080/10705519909540118

Husemann, Katharina C., Florian Ladstaetter, and Marius K. Luedicke (2015), "Conflict culture and conflict management in consumption communities," Psychology \& Marketing, 32, 3, 265-284, doi: 10.1002/mar.20779

Ilhan, Behice Ece, Raoul V. Kübler, and Koen H. Pauwels (2018), "Battle of the brand fans: impact of brand attack and defense on social media," Journal of Interactive Marketing, 43, 33-51, doi:10.1016/j.intmar.2018.01.003 
Illia, Laura, Stefania Romenti, Belén Rodríguez-Cánovas, Grazia Murtarelli, and Craig E. Carroll (2017), "Exploring corporations' dialogue about CSR in the digital era," Journal of Business Ethics, 146, 1, 39-58, doi:10.1007/s10551-015-2924-6

Jerolmack, Colin, and Shamus Khan (2014), "Talk is cheap ethnography and the attitudinal fallacy," Sociological Methods and Research, 43, 2, 1-32, doi:10.1177/0049124114523396

Johnson, Devon S., and Ben Lowe (2015), "Emotional support, perceived corporate ownership and skepticism toward out-groups in virtual communities," Journal of Interactive Marketing, 29, 1-10, doi:10.1016/j.intmar.2014.07.002

Kozinets, Robert V. (2002), "The field behind the screen: Using netnography for marketing research in online communities," Journal of Marketing Research, 39, 1, 61-72, doi:10.1509/jmkr.39.1.61.18935

Kozinets, Robert V. (2015), "Netnography," The International Encyclopaedia of Digital Communication and Society, 1-8, doi:10.1002/9781118767771.wbiedcs067

Kronrod, Ann, Amir Grinstein, and Luc Wathieu (2012), "Go green! Should environmental messages be so assertive?," Journal of Marketing, 76, 1, 95-102, doi:10.1509/jm.10.0416

Labrecque, Lauren I., Jonas vor dem Esche, Charla Mathwick, Thomas P. Novak, and Charles F. Hofacker (2013), "Consumer power: Evolution in the digital age," Journal of Interactive Marketing, 27, 4, 257-269, doi:10.1016/j.intmar.2013.09.002

Lee, Hangwoo (2005), "Behavioural strategies for dealing with flaming in an online forum," The Sociological Quarterly, 46, 2, 385-403, doi:10.1111/j.1533-8525.2005.00017.x

Lee, Yong-ki, Sally Kim, Min-seong Kim, and Jeang-gu Choi (2014), "Antecedents and interrelationships of three types of pro-environmental behavior," Journal of Business Research, 67, 10, 2097-2105, doi:10.1016/j.jbusres.2014.04.018

Liu, Wendy, and Jennifer Aaker (2008), “The happiness of giving: The time-ask effect," Journal of Consumer Research, 35, 3, 543-557, doi:10.1086/588699

Lloyd, Harris, Rebekah Russell- Bennett, and Sven Tuzovic (2010), "Frequent (flier) frustration and the dark side of word-of-web: Exploring online dysfunctional behavior in online feedback forums," Journal of Services Marketing, 24, 6, 446-457, doi:10.1108/08876041011072564

Lovejoy, Kristen, and Gregory D. Saxton (2012), "Information, community, and action: How nonprofit organizations use social media," Journal of Computer-Mediated Communication, 17, 3, 337-353, doi:10.1111/j.1083-6101.2012.01576.x

Matzat, Uwe (2009), "A theory of relational signals in online groups". New Media \& Society, 11, 3, 375-394, doi: $10.1177 / 1461444808101617$

Matzat, Uwe, and Gerrit Rooks (2014), "Styles of moderation in online health and support communities: An experimental comparison of their acceptance and effectiveness," Computers in Human Behavior, 36, 65-75, doi:10.1016/j.chb.2014.03.043

Mathwick, Charla, Caroline Wiertz, and Ko De Ruyter (2008), "Social capital production in a virtual P3 community,” Journal of Consumer Research, 34, 6, 832-849, doi:10.1086/523291

McCollough, Michael A., Leonard L. Berry, and Manjit S. Yadav (2000), "An empirical investigation of customer satisfaction after service failure and recovery," Journal of Service Research, 3, 2, 121-137, doi:10.1177/109467050032002 
Nan, Xiaoli, and Kwangjun Heo (2007), "Consumer responses to corporate social responsibility (CSR) initiatives: Examining the role of brand-cause fit in cause-related marketing," Journal of Advertising , 36, 2, 63-74, doi:10.2753/JOA0091-3367360204

Naylor, Rebecca Walker, Cait Poynor Lamberton, and Patricia M. West (2012), "Beyond the "like" button: The impact of mere virtual presence on brand evaluations and purchase intentions in social media settings," Journal of Marketing, 76, 6, 105-120. doi:10.1509/jm.11.0105

Pew Research Center, (2017), “Online harassment," (Accessed: 5 May 2020), Available at: http://www.pewinternet.org/2017/07/11/online-harassment-2017/

Pfeffer, Jürgen, Thomas Zorbach, and Kathleen M. Carley (2014), “Understanding online firestorms: Negative word-of-mouth dynamics in social media networks," Journal of Marketing Communications, 20, 1-2, 117-128, doi:10.1080/13527266.2013.797778

Plé, Loïc, and Catherine Demangeot (2019, in press), "Social contagion of online and offline deviant behaviors and its value outcomes: The case of tourism ecosystems," Journal of Business Research, doi.org/10.1016/j.jbusres.2019.06.002

Rahim, M. Afzalur (1983), "A measure of styles of handling interpersonal conflict," Academy of Management Journal, 26, 2, 368-376, doi:10.5465/255985

Reeves, Scott, Ayelet Kuper, and Brian David Hodges (2008), "Qualitative research methodologies: Ethnography,” British Medical Journal, 337, 7668, 512-514, doi:10.1136/bmj.a1020

Roschk, Holger, and Susanne Kaiser (2013), "The nature of an apology: An experimental study on how to apologize after a service failure," Marketing Letters, 24, 3, 293-309, doi: $\underline{10.1007 / s 11002-012-9218-\mathrm{X}}$

Runions, Kevin, Jennifer D. Shapka, Julian Dooley, and Kathryn Modecki (2013), "Cyberaggression and victimization and social information processing: Integrating the medium and the message: Correction to Runions et al." (2013). Psychology of Violence, 3, 4, 380. doi: $10.1037 / \mathrm{a} 0034503$

Rust, Roland T., and Bruce Cooil (1994), "Reliability measures for qualitative data: Theory and implications," Journal of Marketing Research, 31, 1, 1-14. doi:10.1177/002224379403100101

Saxton, Gregory D., and Lili Wang (2014), "The social network effect: The determinants of giving through social media," Nonprofit and Voluntary Sector Quarterly, 43, 5, 850-868, doi: $\underline{10.1177 / 0899764013485159}$

Saxton, Gregory D., and Richard D. Waters (2014), "What do stakeholders like on Facebook? Examining public reactions to nonprofit organizations' informational, promotional, and community-building messages," Journal of Public Relations Research, 26, 3, 280-299, doi:10.1080/1062726X.2014.908721

Schamari, Julia, and Tobias Schaefers (2015), "Leaving the home turf: How brands can use webcare on consumer-generated platforms to increase positive consumer engagement," Journal of Interactive Marketing, 30, 20-33, doi:10.1016/j.intmar.2014.12.001

Schau, Hope Jensen, Albert M. Muñiz Jr, and Eric J. Arnould (2009), "How brand community practices create value," Journal of Marketing, 73, 5, 30-51, doi:10.1509/jmkg.73.5.30

Schröder, Monika JA, and Morven G. McEachern (2004), "Consumer value conflicts surrounding ethical food purchase decisions: A focus on animal welfare," International Journal of Consumer Studies, 28, 2, 168-177, doi:10.1111/j.1470-6431.2003.00357.x 
Seraj, Mina (2012), "We create, we connect, we respect, therefore we are: intellectual, social, and cultural value in online communities," Journal of Interactive Marketing, 26, 4, 209-222, doi:10.1016/j.intmar.2012.03.002

Shaw, Deirdre, and Terry Newholm (2002), "Voluntary simplicity and the ethics of consumption," Psychology \& Marketing, 19, 2, 167-185, doi:10.1002/mar.10008

Sibai, Olivier, Kristine De Valck, Andrew M. Farrell, and John M. Rudd (2015), "Social control in online communities of consumption: A framework for community management," Psychology \& Marketing, 32, 3, 250-264, doi:10.1002/mar.20778

Skarmeas, Dionysis, and Constantinos N. Leonidou (2013), "When consumers doubt, watch out! The role of CSR scepticism," Journal of Business Research, 66, 10, 1831-1838, doi:10.1016/j.jbusres.2013.02.004

Skålén, Per, Stefano Pace, and Bernard Cova (2015), "Firm-brand community value co-creation as alignment of practices," European Journal of Marketing, 49, 3/4, 596-620, doi.org/10.1108/EJM-08-2013-0409

Smith, Andrew N., Eileen Fischer, and Chen Yongjian (2012), "How does brand-related usergenerated content differ across YouTube, Facebook, and Twitter?," Journal of Interactive Marketing, 26, 2, 102-113, doi:10.1016/j.intmar.2012.01.002

Strauss, Anselm, and Juliet Corbin (1998). Basics of qualitative research techniques, Thousand Oaks, CA: Sage Publications.

Sudbury-Riley, Lynn, and Florian Kohlbacher (2016), "Ethically minded consumer behavior: Scale review, development, and validation," Journal of Business Research, 69, 8, 2697-2710, doi: $10.1016 /$ j.jbusres.2015.11.005

Teddlie, Charles, and Fen Yu (2007), "Mixed methods sampling: A typology with examples," Journal of Mixed Methods Research, 1, 1, 77-100, doi:10.1177/2345678906292430

Thach, Elizabeth, and Karen J. Thompson (2007), "Trading places: Examining leadership competencies between for-profit vs. public and non-profit leaders," Leadership \& Organization Development Journal, 28, 4, 356-375, doi:10.1108/01437730710752229

Chalmers Thomas, Tandy, Linda L. Price, and Hope Jensen Schau (2013), "When differences unite: Resource dependence in heterogeneous consumption communities," Journal of Consumer Research, 39, 5, 1010-1033, doi:10.1086/666616

Van Noort, Guda, and Lotte M. Willemsen (2012), "Online damage control: The effects of proactive versus reactive webcare interventions in consumer-generated and brand-generated platforms," Journal of Interactive Marketing, 26, 3, 131-140, doi:10.1016/j.intmar.2012.01.003

Vázquez, Rodolfo, Luis Ignacio Álvarez, and María Leticia Santos (2002), "Market orientation and social services in private non-profit organisations," European Journal of Marketing, 36, 9/10, 1022-1046, doi:10.1108/03090560210437316

Yoon, Sukki, Yung Kyun Choi, and Sujin Song (2011), "When intrusive can be likable," Journal of Advertising, 40, 2, 63-76, doi:10.2753/JOA0091-3367400205

Wagner, Tillmann, Richard J. Lutz, and Barton A. Weitz (2009), "Corporate hypocrisy: Overcoming the threat of inconsistent corporate social responsibility perceptions," Journal of Marketing, 73, 6, 77-91, doi:10.1509/jmkg.73.6.77 
Wang, Wenbo, Lu Chen, Krishnaprasad Thirunarayan, and Amit P. Sheth (2014), "Cursing in English on twitter," In Proceedings of the 17th ACM conference on Computer Supported Cooperative Work \& Social Computing (pp. 415-425), Available at: https://dl.acm.org/citation.cfm?id=2531734

Wang, Xia, Chunling Yu, and Yujie Wei (2012), "Social media peer communication and impacts on purchase intentions: A consumer socialization framework," Journal of Interactive Marketing, 26, 4, 198-208, doi:10.1016/j.intmar.2011.11.004

Waters, C. Kenneth (2007), "The nature and context of exploratory experimentation: An introduction to three case studies of exploratory research," History and Philosophy of the Life Sciences, 29, 3, 275-284, doi:23334262

Waters, Richard D., Emily Burnett, Anna Lamm, and Jessica Lucas (2009), "Engaging stakeholders through social networking: How nonprofit organizations are using Facebook," Public Relations Review, 35, 2, 102-106, doi:10.1016/j.pubrev.2009.01.006

Waters, Richard D., and Jia Y. Jamal (2011), "Tweet, tweet, tweet: A content analysis of nonprofit organizations' Twitter updates," Public Relations Review, 37, 3, 321-324, doi:10.1016/j.pubrev.2011.03.002

Waters, Richard D., and Holly K. Ott (2014), "Corporate social responsibility and the nonprofit sector: Assessing the thoughts and practices across three nonprofit subsectors," Public and Non-profit Administration, $8, \quad 3, \quad 1-18 . \quad$ Available at: http://www.prsa.org/intelligence/prjournal/vol8/no3/\#.VXC2Lkbis8A

Wu, Mao-Ying, and Philip L. Pearce (2013), “Appraising netnography: Towards insights about new markets in the digital tourist era," Current Issues in Tourism, 17, 5, 463-474, doi: $\underline{10.1080 / 13683500.2013 .833179}$

Yang, Defeng, Yue Lu, Wenting Zhu, and Chenting Su (2015), "Going green: How different advertising appeals impact green consumption behaviour," Journal of Business Research, 68, 12, 2663-2675, doi:10.1016/i.jbusres.2015.04.004

Ye, Nan, Lefa Teng, Ying Yu, and Yingyuan Wang (2015). “"What's in it for me?": The effect of donation outcomes on donation behaviour," Journal of Business Research, 68, 3, 480-486, doi:10.1016/j.jbusres.2014.09.015

Zane, Daniel M., Julie R. Irwin, and Rebecca Walker Reczek (2016), "Do less ethical consumers denigrate more ethical consumers? The effect of willful ignorance on judgments of others," Journal of Consumer Psychology, 26, 3, 337-349, doi: 10.1016/j.jcps.2015.10.002 
Dear Prof. Ratchford,

We thank you the conditional acceptance of our manuscript INTMAR-D-19-00060R2 and for the suggestions and guidance on improving it provided by you and one of the reviewers. Here, we provide a list of revision notes regarding how we addressed these and where within the manuscript.

\section{Study 1 Method}

In relation to the type of conflict observed in Study 1, the reviewer pointed out the following: "This doesn't appear to be inter-group conflict - rather the themes seem to highlight conflict between groups holding differing belief systems."

$\rightarrow$ Page 11: We incorporated this comment in the first paragraph by including an additional sentence beginning with "It was further confirmed that..."

\section{$\underline{\text { Study } 1 \text { Discussion }}$}

With respect to the 'non-engaging' strategy, the reviewer noted that "it doesn't make sense that they [organizations] hesitate to put limits on what is considered 'out-of-bounds' action or interaction styles" and suggested that we emphasize this.

$\rightarrow$ Page 14: This was emphasized in the second paragraph on this page (the sentence starting "While other studies have...").

\section{Study 2 Measures}

Pages 18, 19 and 40: As per the reviewer's request, we included our measures (dependent and control variables) in a table (Table 4) and removed these from the narrative.

\section{Study 2 Findings}

Pages 20, 40 and 41: We removed our previous tables in this section and included two new tables. Table 5 shows the cell means for the two dependent variables, while Table 6 reports the summary of the two-way ANOVA results including fit and significance measures.

\section{General Discussion - Implications for Research}

1. Pacifying strategy (now renamed to realignment) 
The reviewer noted that "refereeing interactions to ensure they fall within boundaries of civil engagement is an important and unexpected point that I would strengthen in both the contribution and Discussion sections."

$\rightarrow$ Pages 23-24: To address this, we expanded the first and second paragraphs of Implications for Research.

The reviewer further suggested to circle back to Lee's (2005) study discussing competitive dominating strategies "to help elaborate on the role of pacification in the NPO setting."

$\rightarrow$ Page 23: In response to this we included an additional sentence beginning "This extends past research..."

It was pointed out on two occasions by the reviewer that the name of the 'pacifying' strategy is not the right term given what we measure and he/she recommended that we re-name it.

$\rightarrow$ After searching the literature on community engagement and moderation, we observed that a term called 'realignment' represented a reoccurring theme with respect to compliance in online communities. We thus renamed our 'pacifying' strategy to 'realignment' throughout the manuscript and followed Skålén, Pace and Cova (2015) in doing so.

Skålén, Per, Stefano Pace, and Bernard Cova (2015), "Firm-brand community value cocreation as alignment of practices," European Journal of Marketing, 49, 3/4, 596-620, doi.org/10.1108/EJM-08-2013-0409

In relation to 'pacifying', the reviewer noted the following: "I would consider discussing what is actually happening when you tell someone to clean up the language. Linguistic choices online stand in as a surrogate to physical violence and may even lead to it offline. I think this topic is worth elaborating on in your Discussion section."

$\rightarrow$ Page 24: In response to this we included additional information in the first paragraph (sentence starting "Imposing civility as a condition...") to discuss the possible offline consequences of realignment (formerly referred to as 'pacifying').

2. Other-oriented conflict

The reviewer pointed out that the majority of conflicts uncovered in Study 1 revolve around other-oriented issues and that this is surprising considering the context of the NPO we investigate. 
$\rightarrow$ Page 26: To address this, we included a paragraph at the end of the Implications for Research section.

$\rightarrow$ Page 15: We further re-wrote the final paragraph in Study 1 Discussion to better reflect this counter-intuitive finding as well as included this in future research (page 28).

3. Non-engaging

The reviewer asked that we elaborate on non-engaging and the consequences of it since it represents the most frequently occurring strategy in Study 1.

$\rightarrow$ Page 25: In response to this we expanded the second paragraph on this page starting from the sentence "Although it can be speculated..."

\section{$\underline{\text { Future research directions }}$}

Page 28: As per the reviewer's suggestions regarding future research directions we included a paragraph in this section. These included: 1) investigating the newly termed strategy realignment in political forums and advertising contexts; 2) examining the effect of different mobilization strategies as a way to diffuse conflict; 3) investigating the motivations behind non-engaging since it is a dominant strategy; and 4) studying the conflict orientations further with an emphasis on the other-oriented conflict content.

\section{Formatting}

Following the journal's guidelines, the manuscript now adheres to the 50-page all-inclusive limit and the referencing style has been amended to match these guidelines.

Lastly, we would like to apologize for the difficulty in reading created by keeping the "track changes' function on. This was done in order to showcase where and what changes had been made, but we now appreciate that it was not appropriate and we will keep this in mind in future.

We hope that these changes address what the reviewer had in mind and we look forward to hearing from you in due course.

Yours Sincerely,

The authors 
Tom Jacobs Humans are simply disgusting cruel animals, the only truly

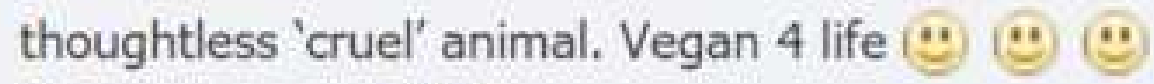

50 minutes ago ' Like

Chris Zaborsky Well since your human and I'm sure you were fed meat as a child and your parents. You should hate yourself 48 minutes ago - Like

Samantha Jones Bit of a jump there @Chris

44 minutes ago - Like

Tom Jacobs I...do and I wish my parents knew how traumatic eating animals was for me as a child. I always loved animals And I was very sensitive to suffering....Wish I could go back as a kid, knowing what I know. I've been vegan for 25 years, but wish it was my whole existence O

40 minutes ago · Like

Adam Payne @Tom has made the choice to be vegan now as an adult when he understands what is happening. He should be proud of himself. He most defiantly should not hate himself"

36 minutes ago ' Like

Tom Jacobs Thanks @Adam Payne (:)

31 minutes ago - Like

Christian Mawson @Chris Zaborsky your an idiot

27 minutes ago - Like

PETA (People for the Ethical Treatment of Animals) Thank you for making a difference for animals by living a vegan lifestyle 25 minutes ago - Like

Write a comment ... 


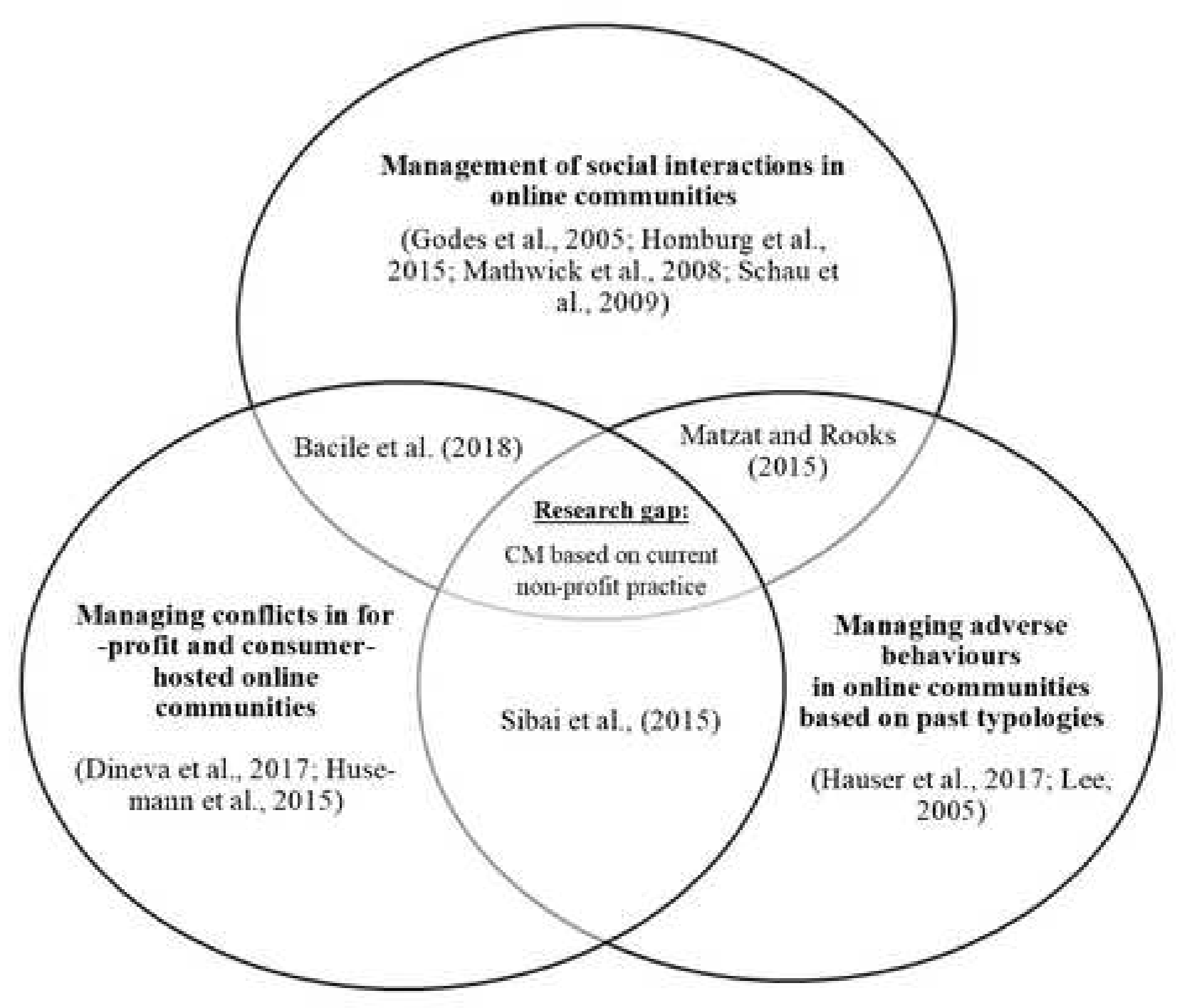

\section{online communities}

015: Mathwick et al.. 2008; Schau et al., 2009)

hosted online

communities

mann et al., 2015)

2005)

\section{behaviours}

Sibai et al.. (2015) 


\section{Initial consultation to the literature on $\mathrm{CM}$}

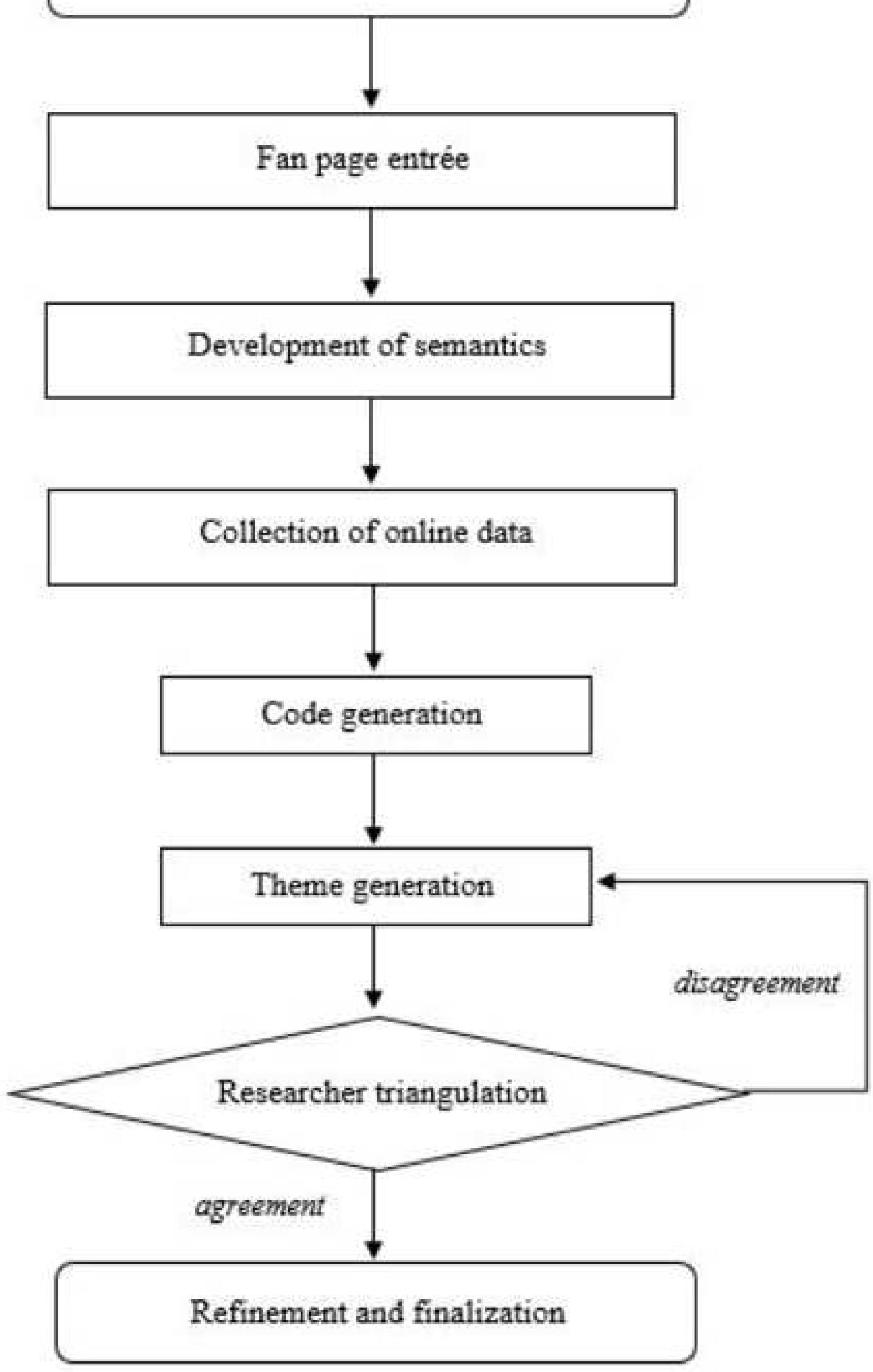


WSEFC WSEFC (World Society for Ethical Food Consumption) o

Dairy consumption is bad for your personal health!

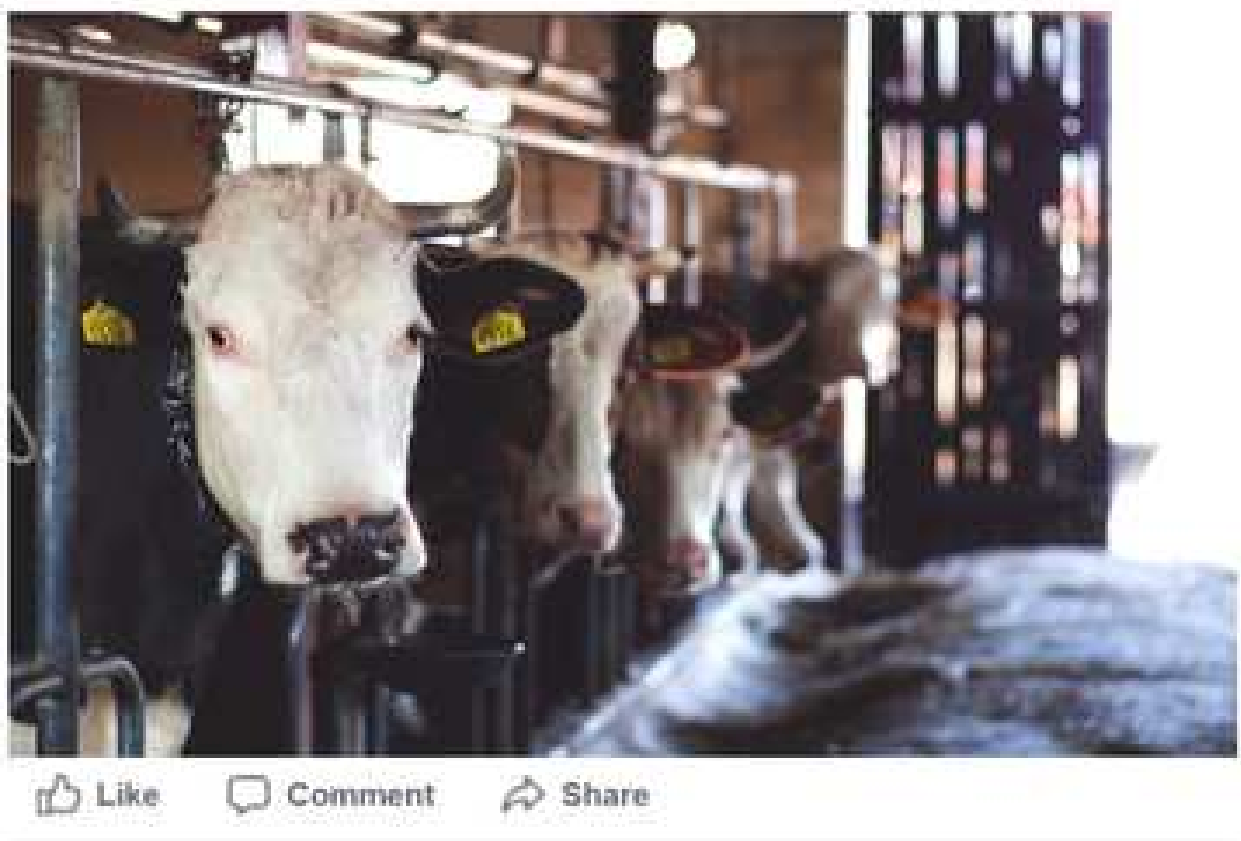

00822

\section{3 shares}

James Nickols The idea that consuming dairy products is bad for your health is ridiculous!

17 minutes ago * Like

Rose Johns Really? seriously you think that dairy consumption is not bad for your health?? go educate yourself!!

15 minutes ago 'Lke

James Nickols Yes dairy consumption is not bad for your health you idiot! Besides personal health is over-rated.

10 minutes ago "Like

Sam Sanford James Nickols you are the idiot! Dairy products are bad for humans. Think about your well-being!

9 minutes ago " Like

Miranda Evans James Nickols you're an asshole! Your rationalization of dairy consumption tells us everything we need to know about you.

Monster!

6 minutes ago " Like

James Nickols Miranda Evans you and your tree hugging friends can mind your own damn business!

4 minutes ago " Like 


\section{WSEFC WSEFC (World Society for Ethical Food Consumption) o 3hrs}

Dairy consumption leads to animal cruelty!

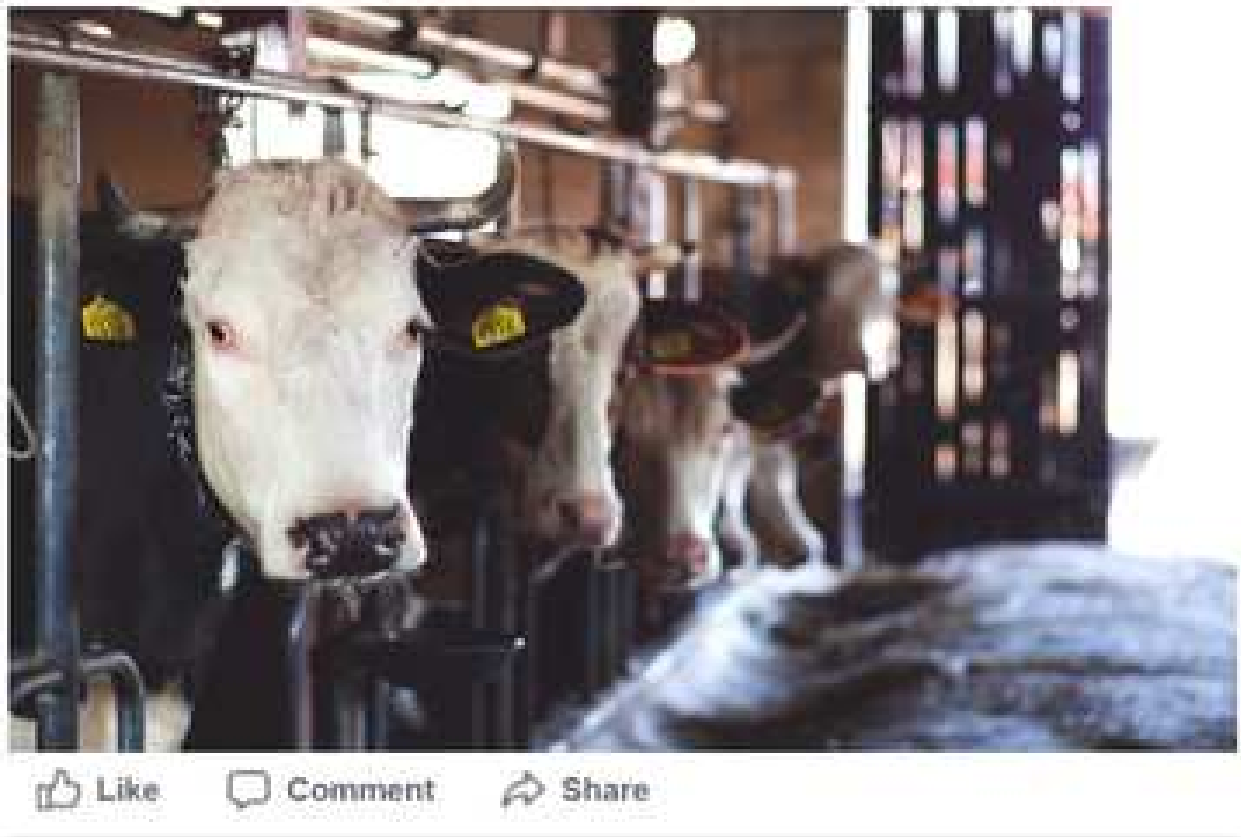

\section{2}

\section{3 shares}

James Nickols The idea that consuming dairy products is linked to animal eruelty is ridiculous!

17 minutes ago : Like

Rose Johns Really? seriously you think that dairy consumption is not felated to animal cruelty?? go educate yourseif!!

15 minutes ago : Like

James Nickols Yes dairy consumption is not cruel you idiot! Besides animal cruelty is over-rated.

10 minutes ago ' Like

Sam Sanford James Nickols you are the idiot! Dairy products are bad for animals. Think about their well-being!

9 minutes ago - Like

Miranda Evans James Nickols you're an asshole! Your rationalization of dairy consumption tells us everything we need to know about you. Monster!

6 minutes ago - Like

James Nickols Miranda Evans you and your tree hugging friends can mind your own damn business!

4 minutes ago - Like 


\section{WSEFC (World Society for Ethical Food Consumption)}

200,000 likes!!! Thank you all for your support!

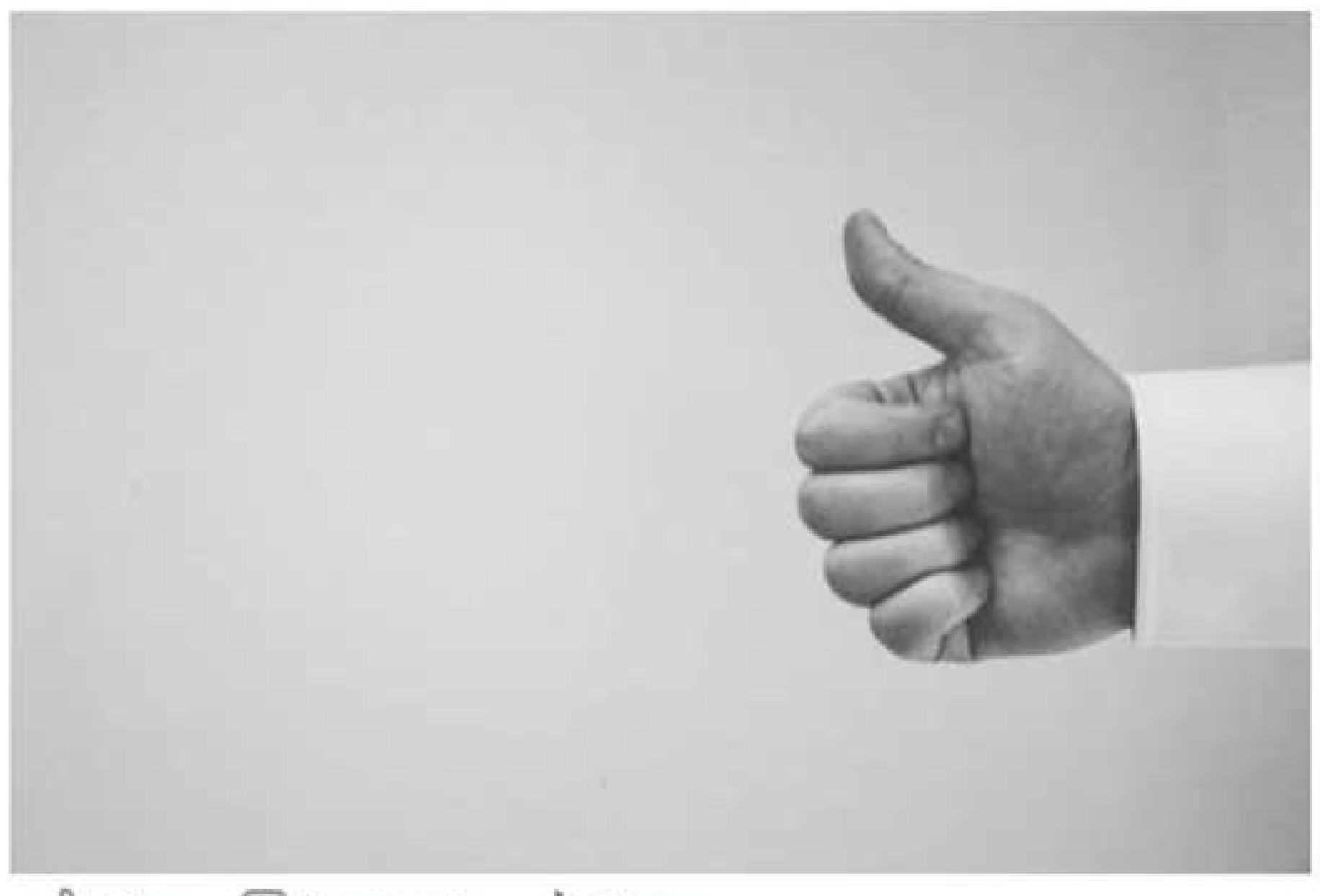

d] Like Comment $\Rightarrow$ Share

\section{CO 206}


B.2 Pacifying (same for both conflict content orientations)

(WSEFC WSEFC (World Society for Ethical Food Consumption): Swearing

will not be tolerated, so can we please watch the language.

11 minutes ago - Like

Write a comment ....

B. 3 Bolstering (same for both conflict content orientations)

(WSEFC

WSEFC (World Society for Ethical Food Consumption): Thank you

all who support our cause!

11 minutes ago ' Like

Write a comment $\ldots$

B.4 Educating (self-benefit content orientation)

WSEFC WSEFC (World Society for Ethical Food Consumption): Experts agree that as much as $90 \%$ of health problems can be related to dairy consumption.

11 minutes ago * Like

Write a comment ...

B.5 Educating (other-benefit content orientation)

wSErc

WSEFC (World Society for Ethical Food Consumption): Experts

agree that as much as $90 \%$ of the dairy industry involves some form of animal cruelty.

11 minutes ago - Like

Write a comment ...

B. 6 Mobilizing (self-benefit content orientation)

WSEFC (World Society for Ethical Food Consumption): Please

WSEFC consider dairy-free alternatives and do your health a favor!

11 minutes ago - Like

Write a comment...

B.7 Mobilizing (other-benefit content orientation)

wSEF

WSEFC (World Society for Ethical Food Consumption): Please

consider dairy-free alternatives and do the animals a favor!

11 minutes ago - Like

Write a comment... 